\title{
NOTES
}

\section{AN ASPECT OF PUBLIC UTILITY RATE VALUATION: THE WORKING CAPITAL ALLOWANCE}

Since 1898 the classic method for setting rates in the public utility field has been to compute a figure high enough to compensate for the utility's operating expenses and to provide an excess amounting to a fair return on the utility's fair investment in property used and useful for the public convenience. ${ }^{1}$ The total valuation on which a return is granted is termed the "rate base." Much controversy has arisen as to the method of attributing "cost" or "value" to the property included in the rate base. There are currently in use several methods for valuing tangible fixed assets $;^{2}$ but fixed assets are only part of the rate base. Intangible assets such as franchises, going concern value, patents, and water rights are usually taken into consideration. ${ }^{3}$ A utility should also be permitted

1. See Smyth v. Ames, 169 U.S. 466, 546 (1898); Barnes, The Economics of Public Utility Regulation 299-314, 318, cc. X, XI (1942); Troxel, Econonics of Public Utilities 260 (1947).

2. So-called "fair value" has been the method with the largest following since Smyth v. Ames, 169 U.S. 466 (1898). That case suggested that “. . . in order to ascertain that value, the original cost of construction, the amount expended in permanent improvements, the amount and market value of its bonds and stock, the present as compared with the original cost of construction, the probable earning capacity of the property under particular rates prescribed by statute, and the sum required to meet operating expenses, are all matters for consideration, and are to be given such weight as may be just and right in each case." Id. at 546. Public representatives urged cost of reproduction as the method of valuation to be emphasized most strongly. See discussion in Justice Brandeis' concurring opinion in Southwestern Bell Tel. Co. v. Public Serv. Comm'n of Missouri, 262 U.S. 276, 289 et seq. (1923), in which he criticizes this method and suggests the prudent investment method. Reproduction cost became the factor in the Smyth $v$. Ames rule most emphasized by the majority of commissions, and eventually was adopted as the measure of fair value. Various corollaries developed, including reproduction cost at unit prices prevailing at the date of valuation, at some date prior to the date of valuation, at a date not specified, at prior dates but including subsequent additions at actual cost or at future predicted prices. Ibid. Other derivatives of the reproduction method included trended cost, piecemeal reproduction, etc. See BARNES, op. cit. supra note 1 , at 416 et seq.

Justice Brandeis' opinion produced many converts to his alternative method, the prudent investment approach, an outgrowth of the original cost method. Rose, The Bell Telephone System Rate Cases, 37 VA. L. Rev. 699, 701 (1951). Other systems of valuation related to original cost include historical and actual legitimate cost. BARNES, op. cit. supra note 1 , at 406 et seq. The most recent development in the valuation process was introduced by FPC v. Hope Natural Gas Co., 320 U.S. 591 (1944), which rejected the requiring of any single method if the rates prescribed by the Commission are ". . . "just and reasonable" within the meaning of the Act. Rates which enable the company to operate successfully, to maintain its financial integrity, to attract capital, and to compensate its investors for the risks assumed certainly cannot be condemned as invalid, even though they might produce only a meager return on the so-called "fair value' rate base." Id. at 605 . And ". . . it is the result reached not the method employed which is controlling." Id. at 602 .

3. BARNES, op. cit. supra note 1, at 439 et seq.; TROXEL, op. cit. supra note 1 , at $260,282-3$. 
to earn a return on its working capital, which is usually defined as the money provided by investors and used for salaries, materials and supplies, other current expenses and certain other cash outlays which must be paid by the utility until reimbursement is obtained from customers. ${ }^{4}$ This capital constitutes just as much an investment in "used and useful" property as money used to purchase fixed plant; so long as it is necessary for investors to supply this working capital, it should earn the same return as fixed capital. 5

However, keeping in mind the purpose for making a working capital allowance-i.e., to pay investors for the use of funds which they must provide for working capital -it can be seen that no allowance should be made for items which, although they may be denominated working capital funds by the utility, are not necessary for that purpose; e.g., an overstatement by the company of materials and supplies requirements should be rejected by the regulatory body. Nor should an allowance be made on working capital funds which, while necessary, are or can be provided not by the investors,

4. See Alabama-Tennessee Natural Gas Co. v. FPC, 203 F.2d 494 (3d Cir. 1953); Pittsburgh v. Pennsylvania PUC, 370 Pa. 305, 88 A.2d 59 (1952) ; Chesapeake \& Potomac Tel. Co. v. Public Serv. Comm'n of Maryland, 93 A.2d 249 (Md. 1952); Maine PUC v. Bangor Hydro-Elec. Co., 92 P.U.R. (N.S.) 46 (Me. 1952); Pacific G. \& E. Co., CCH 1953 State Utre. Law Rep. II 16350 (Cal. 1952); Hackensack Water Co., CCH 1947 State Utrl. Law Rep. If 15690 (N.J. 1949). See also BARNEs, op. cit. supra note 1 , at 495 .

5. In attributing an amount to the tangible fixed assets included in the rate base, no distinction is made as to the source of funds used to purchase those assets. Thus, the cost (in an "original cost" jurisdiction) or value (in a "fair value" jurisdiction) of a tangible asset is included in the rate base at the same figure regardless of whether it was purchased with funds obtained from stockholders, bondholders, or creditors. But in computing the fair rate of return which the utility is to be permitted to earn on the entire rate base, the sources of funds are considered. The fair rate is a figure which considers either the actual relative equity and debt capital structure of the company or a hypothetical capital structure if the actual structure would lead to clearly unfair rates. Rose, The Bell Telephone System Rate Cases, 37 VA. L. REv. 699, 713 et seq. (1951). But apparently in neither case is the generally lower cost of short-term financing (i.e., credit from suppliers, banks, or parent companies) taken into consideration. This is because a company seldom possesses continuing ability to borrow from creditors to finance plant acquisition and expansion at a lower rate of interest than it pays to its stockholders or bondholders. But while a utility could seldom finance permanent investment in plant from borrowings, it can borrow working capital. Hence, applying the fair return to the funds supplied for working capital purposes without considering all of the sources permits the investors to earn a greater return on their working capital funds than those funds cost. Two solutions are possible. A "fair rate" could be computed which takes into consideration the cost of all sources of funds (i.e., interest on stocks, bonds, and short-term loans). But this would penalize the investor by applying a lower rate to items in the rate base such as fixed assets which are not financed from short term loans. Or working capital could be treated separately with a "fair return" granted on items supplied by investors (stock- and bondholders); a lesser rate (computed on the basis of out-of-pocket cost of borrowing) applied to items supplied by short-term creditors and parent companies; and no return on items purchased from funds supplied by consumers which cost the utility nothing. It might be suggested, however, that all funds supplied by consumers, including those paid in advance of the date of the company's liability for the services, belong to the investors, provided they constitute payments for services rendered by the utility, and should therefore earn a return. This argument has been judicially rejected (see cases cited note 4 supra) on the premise that requiring a fair return on contributions forced from customers in advance of the company's payment for services rendered amounts to a double charge. 
but by consumers, employees, or creditors. For example, the funds used for working capital may be supplied by that portion of revenues representing operating taxes ${ }^{6}$ collected from consumers in advance of the date on which the utility pays the taxes for the period in which those revenues were received. To permit the utility to earn a return on money supplied by the consumer means that the consumer has foregone the use of such money for a considerable period of time and is also being required to pay interest to the utility, in the form of a fair return, on those same funds. This amounts to a double charge to the public. Where the consumer has supplied the working capital funds, there is no need to encourage investment by the working capital allowance. Since this allowance customarily averages between two and five percent of the rate base, ${ }^{7}$ denial of an unnecessary allowance could represent a sizeable saving to the public. ${ }^{8}$ Yet in the past many regulatory bodies ${ }^{9}$ have granted a working capital allowance as a matter of right. ${ }^{10}$ Over the years there has been a growing tendency to

6. The term "operating taxes" is used here to refer to those taxes imposed on the utility itself. It includes state shares, franchise, gross receipts and property taxes, state and federal income and unemployment taxes, and employer contributions to social security taxes. Returns are filed and these taxes are almost always paid after the period for which they are imposed. The company also generally acts as the government's agent for the collection from customers of excise taxes (federal, state and local), payroll taxes withheld from employees for income taxes, and employee contributions to social security taxes. These are normally paid over to the government either monthly or quarterly, and are consequently available for use for a much shorter time, if at all. See discussion, text at notes 106, 125, and 126 infra. For a discussion of taxes in rate regulation see TROXEL, op. cit. supra note 1, at 250-7; BARNES, op. cit. supra note 1 , at 621-3.

7. Barnes, op. cit. supra note 1, at 499 ; Bauer and Gold, Public Utilitix VAlUation 299 (1934).

8. For example, in Pittsburgh v. Pennsylvania PUC, $370 \mathrm{~Pa} .305,88$ A.2d 59 (1952), the commission arrived at a rate base of $\$ 410,000,000$, including $\$ 6,200,000$ working capital (only $1.5 \%$ of the rate base). The disallowance by the court of such working capital saved consumers $\$ 372,000$ a year (since the fair return found by the commission and approved by the court was $6 \%$ ). Of course, this saving is not necessarily passed on directly to the consumer, since total expected revenues are at best a guess of the anticipated demand at the proposed rates, and since rates or fares are not set to a fraction of a cent, but are rounded to the nearest penny or even nickel. In this case, for example, the commission had allowed $\$ 136,771,090$ as total operating costs; a saving of $\$ 372,000$ amounts to less than a $.3 \%$ reduction. If this were the only item on which the court disagreed with the commission there probably would have been no remand. However, when several of these items are added together they may become an important saving to the consumer.

9. This Note refers to the policies of individual regulatory bodies rather than to policies of a particular state, since opinions written by commissions concerning their working capital computation, even within a state and within a short period of time, often show little consistency of treatment. E.g., compare Pittsburgh v. Pennsylvania PUC, $370 \mathrm{~Pa}$. 305, 88 A.2d 59 (1952) (disallowing working capital because offset by accrued federal taxes); Pennsylvania PUC v. Scranton-Spring Brook Water Serv. Co., $28 \mathrm{~Pa}$. P.U.C. 424, 445-6 (1950) (cutting requested allowance because offset by revenue collected in advance), with Greensburg v. Peoples Natural Gas Co., 29 Pa. P.U.C. 181, 190-1 (1950) (offsetting revenues collected in advance from customers against required bank balances only); Pennsylvania PUC v. Duquesne Light Co., 29 Pa. P.U.C. 674, 694-8 (1951) (cutting the requested allowance without mention of offsetting taxes); Pennsylvania PUC v. Saxonburg H. \& L. Co., $28 \mathrm{~Pa}$. P.U.C. 100, 112 (1949) (working capital is an inherent inclusion in the rate base). General trends can, however, sometimes be distinguished. See text at notes 19-21 infra.

10. E.g., Manitowac v. Wisconsin F. \& L. Co., P.U.R. 1927D 737, 745 (Wis. 1927); Southwestern Bell Tel. Co., P.U.R. 1921B 516, 520 (Ark. 1920); Kansas 
scrutinize more closely the necessity of items allegedly creating a working capital requirement, ${ }^{11}$ but formerly only a few commissions and courts took into consideration the purpose for a working capital allowance in determining whether such an allowance should be granted. ${ }^{\mathbf{1 2}}$ Several recent cases, however, have indicated more searching inquiry into the source of funds on which a working capital allowance is requested, on the theory that no allowance should be awarded when consumers themselves, rather than investors, supply this capital through their payment of certain expenses in advance. ${ }^{13}$ Yet, even these recent cases do not provide a satisfactory analysis of all of the requirements and sources of working capital which should be considered in determining the allowance. The purpose of this Note is to examine methods which have been used to determine the working capital allowance, and to make suggestions for bringing the computation more in line with the purpose behind the allowance.

Dearth of Court Decisions:-It should be noted that few court decisions discuss the disposition of the working capital claim ; ${ }^{14}$ most of the law on the subject comes from commissions, rather than courts. There are several reasons for this. The computation is highly technical, and courts lacking expertise and facilities needed for determining the necessary facts are prone to defer to the commissions' determinations, even aside from the usual statutory provision limiting the scope of review of such questions. ${ }^{15}$ Also, the major controversy over the method of fixed asset valuation tends to cause records of rate investigations to become exceedingly long and complex, and since the working capital computation constitutes a relatively small portion of that record it is given little, if any, consideration. Finally, on appeal from a commission's order both utilities and consumer groups would logically prefer to concentrate on issues, such as the type of fixed asset valuation, which might represent more substantial savings, rather than to support a position which will detract time and attention from larger issues. $^{16}$ The fact that working capital averages only two to five percent of the rate base has led many commissions and courts to disregard the

City Elec. L. Co., P.U.R. 1917C 728, 751 (Mo. 1917) ; Richmond L.H. \& P. Co., P.U.R. 1917B 300, 308 (Ind. 1916). See BAUER AND GoLD, op. cit. supra note 7, at 299, 300. Cf. Stecher, The Determination of Working Capital in Railroad and Public Utilities Valuations, 39 Y ALE L.J. 927, 931 (1930); III-A Sharfaran, THE INTERSTATE COMMERCE COMMISSION $511 \mathrm{n}$. (1935).

11. See, e.g., cases cited notes $42-44,46$ and 51 infra.

12. See, e.g., cases cited notes 35, 90, 107 and 108 infra.

13. Cases cited note 4 supra. See also Comment, Cash Working Capital as an Element of the Telephone Rate Base, 52 CoL. L. REv. 673 (1952).

14. Out of over 150 cases, only about 20 court opinions were found on point; many of these merely approved the decision of the commission with little or no discussion. The same paucity of discussion seems to have been noticed by other writers in the field. See Stecher, supra note 10, at 931, and BARNEs, op. cit. supra note 1, at 496.

15. BARnes, op. cit. supra note 1, at 201, 393 et seq.; FPC, State Commission JURISDICTION AND REgulation OF Electric aND Gas UTILITIES 14 (1948).

16. This was suggested to the writer both by an attorney who has represented consumer interests in several rate cases, and by officials of a large public utility. 
allowance entirely as being trivial, ${ }^{17}$ or to use it as a sop to the interest which has lost the fight on the major issue of valuation. ${ }^{18}$ Thus, there is some tendency for jurisdictions which have adopted tangible asset valuations most favorable to investors to scrutinize more carefully the working capital allowance, ${ }^{19}$ while jurisdictions adhering to the more stringent valuation methods are most cavalier in granting the allowance. ${ }^{20}$ There are, however, significant divergencies. ${ }^{21}$

\section{Definitions and Concepts of Working Capital}

The generic term "working capital" encompasses two items: working cash, and materials and supplies. Working cash is required to bridge the gap between expenditures for the production of service and the receipt of payments from consumers. It represents the amount needed to pay for salaries, services, current bills, and to maintain a sound financial position. ${ }^{22}$ The Pennsylvania commission defines it as the amount of money needed by a new enterprise for operating purposes until corresponding revenues are collected. ${ }^{23}$ Materials and supplies represents the inventory needed

17. E.g., Southwestern Bell Tel. Co. v. Public Serv. Comm'n of Missouri, 262 U.S. 276, 283 (1923) (omitted discussion of the allowance because it amounted to an "unimportant reduction"); Colorado Interstate Gas Co., CCH FEDERAL UTIL. LAW REP. IT 9295 (FPC 1952) (denying rehearing after commission refused allowance, calling it "de mirrimis"); Mountain States Tel. \& Tel. Co., 94 P.U.R. (N.S.) 33, 44 (Colo. 1952) (some allowance made despite ability to borrow cheaply and accrued taxes available); New Jersey Bell Tel. Co., 91 P.U.R. (N.s.) 161, 182 (N.J. 1951) (some allowance granted despite fact that tax accruals would fully cover the needs).

18. E.g., Citizens Tel. Co. v. Public Serv. Comm'n of Kentucky, 247 S.W.2d 510, 513 (Ky. 1952) (affirming disallowance since "cushion" provided by excess of rate base over book cost "more than offsets" it); Western Carolina Tel. Co., CCH 1953 State UTII. LAW REp. \16375.01 (N.C. 1953) (allowance granted to offset the high cost of construction).

19. See, e.g., Pittsburgh v. Pennsylvania PUC, 370 Pa. 305, 88 A.2d 59 (1952) and Chesapeake \& Potomac Tel. Co. v. Public Serv. Comm'n of Maryland, 93 A.2d 249 (Md. 1952); both were following the fair value method of valuing tangible assets customarily used in those states.

20. See, e.g., Mountain States Tel. \& Tel. Co., CCH 1950 State UriL. LAw REP. \16228 (Colo. 1952) and Springfield City Water Co., 83 P.U.R. (N.S.) 213 (Mo. 1949); both were following an original cost method.

21. See, e.g., the following cases which do not offset tax accruals even though using a fair value rate base: Cincinnati \& Suburban Bell Tel. Co., CCH 1953 STATE UTIL. LAw REP. \16485 (Ohio 1953) (reproduction cost new); Public Serv. Co. of New Mexico, 84 P.U.R. (N.S.) 451 (N.M. 1950) (reproduction cost new considered). The following cases scrutinize working capital carefully even though adopting a stringent tangible asset valuation: Alabama-Tennessee Natural Gas Co. v. FPC, 203 F.2d 494 (3d Cir. 1953) (prudent investment); Cambridge Elec. I. Co., 96 P.U.R. (N.S.) 77 (Mass. 1952) (prudent investment); PUC v. Bangor Hydro-Elec. Co., 92 P.U.R. (N.S.) 46 (Me. 1952) (average present investment); Hackensack Water Co., CCH 1947 STATE UTIL. LAW Rep. $\mathbb{1} 15690$ (N.J. 1949) (book cost). Again it is to be noted that there is not always consistency even within a state. See note 9 supra.

22. See Jacksonville Gas Co. v. Jacksonville, 82 P.U.R. (N.s.) 67, 80 (Fla. 1949); see also BARNES, op. cit. supra note 1 , at 495 et seq.

23. Fleisher v. Harrisburg Suburban Water Co., 29 Pa. P.U.C. 302, 314 (1951); Pittsburgh v. Pittsburgh Ry., 29 Pa. P.U.C. 778, 786 (1951). 
continuously to keep the enterprise operating and in repair. ${ }^{24}$ While almost all companies have some requirements of working cash and materials and supplies, this does not mean that a company is entitled to an allowance if there are sufficient sources of funds to meet those requirements without the use of investors' money.

Some confusion has arisen from the fact that the term "working capital" can be used in at least three different contexts, depending on the purpose of the user. The first is the accountant's "balance sheet" concept of the excess of specific current assets over current liabilities; ${ }^{25}$ exactly which assets and which liabilities, if any, should be included is a matter of controversy among accountants. ${ }^{26}$ This balance sheet concept is of particular interest to prospective short-term creditors, since it is designed for the purpose of determining at any particular moment whether a concern is in a position fluid enough to meet its short-term debts. The accountant's concept actually refers to the requirements of the utility. Another context in which the term "working capital" is used is that adopted by the manager of the company, who is interested in maintaining a supply of funds at all times to meet current expenses such as payrolls and currently maturing debts, to maintain minimum required bank balances and sufficient inventories, and to meet emergencies; at the same time he must refrain from unnecessarily tying up capital in nonproductive capacities. The manager is largely interested in the amount of cash requirements he will have to meet; the sources from which he derives funds to satisfy those needs are unimportant to him. He may obtain the required funds from current sales, payment of receivables, loans from creditors or parent companies, sale of stock or bonds, or from surplus or reserves; no simple balance sheet study of assets and liabilities supplies him with all of the information requisite for efficient management. In fact, his study seldom differentiates working capital requirements from other cash outlays, including cash needed for plant expansion and investment.

A rational determination of the working capital allowance requires recognition of a third, or regulatory, concept of working capital. This concept involves a consideration of both management's requirements and the sources from which those requirements can be met, since the purpose of the regulatory allowance should be to reimburse investors for the use of only those funds which investors must supply to meet the working capital requirements. A public utility, like any other company, has the right to manage its own fiscal and operating affairs to the fullest extent consistent with public interest; neither the commission nor the court is authorized to interfere with managerial decisions unless the management

24. Jacksonville Gas Co. v. Jacksonville, 82 P.U.R. (N.s.) 67, 80 (Fla. 1949); Public Serv. Comm'n v. Great Northern Util. Co., P.U.R. 1929B 176, 197 (Mont. 1929) ; BaRNES, op. cit. supra note 1 , at 495.

25. Finney, Principles of Accounting, Intermediate 523 et seq. (3d ed. 1946) ; Accounting Research Bull. No. 30, Working Capital 247, 248 (A.I.A. Aug. 1947).

26. Ibid. 
has abused its discretion. ${ }^{27}$ Therefore, considerable weight should be given to managerial decisions as to the amount of the requirements. ${ }^{28}$ However, it does not follow that the consumer should be required to pay a return on more than that amount of capital which is essential to economical and financially sound operation, and which the commission determines is necessarily obtained from the investors. ${ }^{20}$ For example, if a utility's operators decide that a certain sum must be kept on hand at all times for working capital requirements, and that all of these funds should be set aside from the proceeds of sale of stock, this would not preclude the regulating commission from reducing or disallowing the amount of working capital requested in the rate base if it found either that the amount of the requirements was substantially overestimated, or that the funds were available from other sources, such as bank borrowings or current revenues, which would not require the use of investors' funds. Should the commission determine that because of the company's practice of billing customers at the end of the month, the company lacks sufficient funds to pay its currently maturing expenses, it might refuse any allowance to the company. This would induce the company to change its billing practices or to seek funds elsewhere, since it could not long continue to obtain funds from investors without being able to pay them a fair return. This would not necessarily change management's immediate policy and practice, but it would preclude charging customers a return on the amount which the commission has concluded is being inefficiently applied. The regulatory determination of both the legitimate amount of requirements and the most efficient applications of sources of funds are discussed below. ${ }^{30}$

\section{Early Methods of Approach}

The early history of rate regulation suggests that confusion resulted from a failure to analyze the purpose for granting an allowance for working capital. For some time, the proposition that all utilities are entitled to a working capital allowance as a matter of right was commonly ac-

27. Pennsylvania P. \& L. Co. v. Public Serv. Comm'n, $128 \mathrm{~Pa}$. Super. 195, 210-1, 216-7, 193 At1. 427, 434, 436-7 (1937). Cf. West Ohio Gas Co. v. Public Serv. Comm'n of Ohio, 294 U.S. 63, 67, 72-3 (1935); Southwestern Bell Tel. Co. v. Public Serv. Comm'n of Missouri, 262 U.S. 276, 289 (1923).

28. See Cheltenham \& Abington Sewerage Co. v. Public Serv. Comm'n, $122 \mathrm{~Pa}$. Super. 252, 257-8, 186 Atl. 149, 153 (1936) ; Commonwealth Water Co., 6 N.J. Public Serv. Comm'r Rep. 662, 694 (1918). It is important to keep in mind that a disallowance of any working capital in the rate base will not preclude the company from meeting its bills. 'The allowance is simply a determination of whether rates charged to the consumer should be high enough to produce revenue sufficient to include a fair return on the money which will actually be used to pay those bills. Whether those rates are high or low, the company will, in the ordinary course of business, meet its expenses. See Pittsburgh v. Pennsylvania PUC, 370 Pa. 305, 313, 88 A.2d 59, 63 (1952).

29. Pennsylvania P. \& I. Co. v. Public Serv. Comm'n, 128 Pa. Super. 195, 210-1, 216-7, 193 At1. 427, 434, 436-7 (1937).

30. See page 506 et seq. for a discussion of requirements, and page 512 et seq. for a discussion of sources of funds. 
cepted. ${ }^{31}$ In fact, this proposition still recurs in some opinions. ${ }^{32}$ No such generalization should be made; the necessity for an allowance should be determined from the facts of each case. Several methods have been used in computing the necessity for and the amount of working capital.

\section{Working Cash}

Balance Sheet Approach:-The conclusion that all utilities are entitled to working capital allowances as a matter of right led many commissions to grant an allowarice regardless of the sources of working capital or the necessity for such an allowance. ${ }^{33}$ Many assumed that an analysis of the balance sheet, including such current assets as cash on hand and bank deposits, accounts receivable, materials and supplies, and prepayments of expenses, indicated the actual amount of working capital kept by the management during the period studied, and for which an allowance should be made. ${ }^{34}$ Some commissions did require the offsetting of various current liabilities, such as accounts payable, accrued wages and salaries, accrued taxes and interest, customers' deposits, and reserves, ${ }^{35}$ on the theory that net assets maintained in the exercise of managerial discretion constitutes the proper allowance in the rate base. In setting the allowance at the amount of cash kept on hand by the company, even if current liabilities are offset, commissions lose sight of the facts that the company's position may be largely of its own making, ${ }^{36}$ and that much of the cash kept on hand may represent dividend payments, debt retirement, interest payments,

31. See note 10 supra.

32. Pennsylvania PUC v. Saxonburg H. \& L. Co., 28 Pa. P.U.C. 100, 112 (1949); Mountain States Tel. \& Tel. Co., 94 P.U.R. (N.S.) 33, 44 (Colo. 1952); Duke Power Co., CCH 1950 State Util. LaW Rep. đ1 16226.03 (N.C. 1952).

33. See notes 10 and 32 supra.

34. Municipal Gas Co. v. Public Serv. Comm'n, 113 Misc. 748, 752, 186 N.Y. Supp. 541, 545 (Sup. Ct. 1920) ; Manitowac v. Wisconsin F. \& I. Co., P.U.R. 1927D 737,745 (Wis. 1927) ; Aluminum Goods Mfg. Co. v. LaClede Gas Light Co., P.U.R. 1927B 1, 12-3 (Mo. 1926); Portage v. Portage Water Co., P.U.R. 1917D 17, 27-8 (Pa. 1917). Cf. New York Tel. Co., P.U.R. 1923B 545, 610-3 (N.Y. 1923); New York Tel. Co., P.U.R. 1926E 1, 16, 49, 130 (N.Y. 1926) (refusing to offset accounts payable).

35. Public Serv. Comm'n v. Mountain States Tel. \& Tel. Co., P.U.R. 1924C 545, 578-9 (Mont. 1924) (deducting various payables); Western Colo. Power Co., P.U.R. 1918E 629, 644 (Colo. 1918) (deducting current liabilities); Terminal Taxicab Co., P.U.R. 1915B 546, 551 (D.C. 1915) (deducting accounts payable and portions of prepaid expenses). Some decisions even suggested excluding certain assets; $e_{\text {. }}$., Champaign \& Urbana Water Co., P.U.R. 1919E 798, 819 (I11. 1919) (deducting sinking funds from the current assets considered). BARNES, op. cit. supra note 1 , at 498 , and TROXEL, op. cit. supra note 1 , at 283 , would not only deduct current liabilities from current assets, but would not consider all current assets in making a balance sheet study of working capital.

36. "It does not appear that respondent's actual working capital should be given any consideration in fixing cash working capital for rate-making purposes, for the reason that respondent's actual working capital position may be largely of its own making, depending upon, for example, the pay out ratio for dividends on capital stock. There are, of course, many other factors which are largely of respondent's own choosing which make for a good or poor actual working capital position." Pennsylvania PUC v. Duquesne Light Co., 29 Pa. P.U.C. 674, 697 (1951). See also Pennsylvania PUC v. St. Marys Water Co., 36 P.U.R. (N.S.) 75, 81 (Pa. 1940). 
or surplus cash on hand. ${ }^{37}$ The payment of all of these are legitimate exercises of managerial discretion, but funds set aside for such purposes should not earn a return from the consumers. ${ }^{38}$ Dividends and surplus cash are residual items representing profits derived from customers. To require customers to pay a further fair return on such funds would amount to a double exaction. Funds for debt retirement pose a different problem. They are fixed charges, not residual payments, and are paid by investors out of profits, since they are not included among the operating expenses. But funds for their payment should not necessarily earn a fair return, since the assets they purchased are already included in the rate base. Finally, funds for interest payments, like dividends, represent a cost of capital. They are not included in operating expenses in computing rates, and therefore are paid ultimately by investors out of profits. But at the same time short-term interest rates, which are generally lower than either bond or stock interest rates, are not considered in computing the fair rate of return. Consequently, the fair rate is higher than it would otherwise be; this fair rate is applied to the entire rate base, and thereby compensates for the failure to reimburse the investors for interest charges. It follows that these funds should not necessarily be included as a working capital item on which a return is granted.

The balance sheet method was never widely used, and is criticized today. ${ }^{38}$ On the other hand, commissions which, in using this method, required the offsetting of current liabilities against current assets showed an incipient recognition of the fact that not all cash is supplied by investors; when money is obtained by borrowing or buying on credit (as indicated by accounts and notes payable), the consumer should not be required to pay a fair return on that sum although he should be required to pay any actual out-of-pocket cost of borrowing. Recently, one court in denying an allowance concluded that since current liabilities exceeded the company's net assets, any necessary working capital was supplied by creditors. ${ }^{40}$ But even this analysis of the source of working capital is based on the fallacious premise that the net assets maintained actually represent the working capital requisite for efficient operation.

Expense Approach:-Some commissions started at an early period to base their allowances on the operating expenses and certain other cash outlays of the utilities; ${ }^{41}$ but even here there was often no clear analysis

37. See Pittsburgh v. Pennsylvania PUC, $370 \mathrm{~Pa} .305,312,88$ A.2d 59, 63 (1952); Pennsylvania PUC v. Duquesne Light Co., 29 Pa. P.U.C. 674, 697 (1951); Central Vt. Public Serv. Corp., 82 P.U.R. (N.S.) 601, 607 (Vt. 1949); Public Serv. Comm'n of Missouri v. St. Louis County Gas Co., 49 P.U.R. (N.S.) 65, 113 (Mo. 1943); Customers v. New York \& R. G. Co., 48 P.U.R. (N.S.) 25, 38 (N.Y. 1943).

38. Ibid.

39. See, e.g., Pittsburgh v. Pennsylvania PUC, 370 Pa. 305, 312, 88 A.2d 59, 63 (1952), and note 36 supra.

40. Salt Lake City Lines, CCH 1947 State Utrl. Law Rep. 115594.02 (Utah 1949); cf. Southwestern Bell Tel. Co., 87 P.U.R. (N.S.) 97, 111 (A.rk. 1951).

41. For an extended discussion of the method used by commissions prior to 1930 , and for one suggested expense approach to the working capital allowance computa- 
of the purpose and method of computing the working capital allowance. In determining the annual amount of allowable operating expenses, these commissions have properly deducted such items as taxes, which are included in revenues collected from customers long before the company becomes liable for them to the government; ${ }^{42}$ depreciation, which does not involve a cash outlay; ${ }^{43}$ and items such as purchased gas, which are paid for by customers prior to payment by the company. ${ }^{44}$ Some have included funds for non-expense items which require cash outlays, such as petty cash accounts and minimum bank balances, ${ }^{45}$ although the latter have been excluded when it was demonstrably cheaper for the company to pay the service charge or to obtain a loan at interest from a parent company or bank rather than to maintain such balances. ${ }^{46}$ After determining the annual amount of allowable operating expenses, commissions have allocated as the working capital allowance in the rate base an arbitrary fraction of these expenses-the expenses of $15,{ }^{47} 30,4845^{49}$ days, or other percentages of annual expenses ${ }^{50}$-or a portion determined by a study of the actual lag

tion, the "Field" method used by the ICC, which does take into consideration to some extent both requirements and sources, see Stecher, sitpra note 10 . The Field method is described in more detail beginning at note 52 infra. See also West Palm Beach Water Co. v. West Palm Beach, P.U.R. 1930A 177, 195 (S.D. Fla. 1929).

42. See, e.g., Norfolk v. Chesapeake \& Potomac Tel. Co. of Virginia, $192 \mathrm{Va}$. 292, 306, 64 S.E.2d 772, 780 (1951); Pennsylvania W. \& P. Co., 8 F.P.C. 1, 75 (1949); Interstate Power Co., 2 F.P.C. 71, 85 (1939); Hoffman v. Elmira W.L. \& R.R., P.U.R. 1921C 409, 420 (N.Y. 1921).

43. Ibid.

44. Pennsylvania W. \& P. Co., 8 F.P.C. 1, 75 (1949) ; Memphis Natural Gas Co. 3 F.P.C. 566,569 (1943); Cleveland v. Hope Natural Gas Co., 3 F.P.C. 150, 174 (1942), aff'd, 320 U.S. 591 (1944) ; Detroit v. Panhandle Eastern Pipe Line Co., 3 F.P.C. 273,283 (1942).

45. Public Serv. Co. of New Mexico, 84 P.U.R. (N.s.) 451, 453 (N.M. 1950) (cash allowance for making change in payment of bills, etc.); Colorado Springs L.H. \& P. Co., P.U.R. 1916A 872, 882 (Colo. 1915) (cash balances) semble.

46. See, e.g., Pittsburgh v. Pennsylvania PUC, $370 \mathrm{~Pa} .305,314,88$ A.2d 59, 63 (1952); Maine PUC v. Bangor Hydro-Elec. Co., 92 P.U.R. (N.S.) 46, 53 (Me. 1952) ; Pfeifle v. Pennsylvania P. \& L. Co., 57 P.U.R. (N.s.) 1, 23-4 (Pa. 1945). Cf. Greensburg v. Peoples Natural Gas Co., 29 Pa. P.U.C. 181, 191 (1950); Cleveland Elec. Illum. Co. v. Cleveland, 67 P.U.R. (N.S.) 65, 83 (Ohio 1947). Note, however, that the commissions disallowing funds for minimum bank balances have not made provision for payment to the company for the service charges they would have to pay or interest payments on loans to meet those balances, since both service charges and interest payments are considered non-operating expenses. If no fair return is to be granted, at least the additional costs should be met by consumers rather than by investors.

47. Puget Sound Navigation Co., CCH 1947 State Util. LAw REP. $\llbracket 15152.04$

(Wash. 1947) (1/24 annual operating expenses).

48. Philadelphia Trans. Co. v. Pennsylvania PUC, 155 Pa. Super. 9, 29-30, 37 A.2d 138, 147 (1944); Pennsylvania PUC v. Johnstown Traction Co., CCH 1947 State UTIL. LAW REP. \15481.01 ( $\mathrm{Pa}$. 1948) (apparently excluding certain items from expenses).

49. Cleveland Elec. Illum. Co. v. Cleveland, 67 P.U.R. (N.s.) 65, 83 (Ohio 1947) ; Pfeifle v. Pennsylvania P. \& L. Co., 57 P.U.R. (N.S.) 1, 23 (Pa. 1945); Mississippi River Fuel Corp., 4 F.P.C. 340, 344 (1945); Memphis Natural Gas Co., 3 F.P.C. 566, 569 (1943); Detroit v. Panhandle Eastern Pipe Line Co., 3 F.P.C. 273, 283 (1942).

50. Consolidated Edison Co. of New York, 96 P.U.R. (N.s.) 194, 268-74 (N.Y. 1952) (differed for each item of expense); Bell Tel. Co. of Nevada, 82 P.U.R. (N.S.) 529,537 (Nev. 1949) (1/18 operating expenses); Cincinnati G. \& E. Co. v. Cin- 
in receipts. ${ }^{51}$ This method recognizes to some extent the propriety of including only actual requirements, but the arbitrary choice of the percentage of expenses to be included limits its accuracy. It also fails to take into account the various sources from which those requirements may be met without using funds supplied by stockholders and bondholderssources such as current billings of customers, receipts from currently maturing investments or receivables, credit extended by suppliers, and loans from banks and other creditors or parent companies.

In $1928^{52}$ the Interstate Commerce Commission adopted a method (still followed in valuation proceedings today) ${ }^{53}$ of computing the working capital allowance which gives some consideration to both requirements of the company and the sources from which those requirements are met. The commission first computes the amount of invested cash necessary, if any, to pay outlays for carrier service falling due prior to the time when there are available cash receipts from customers applicable to such outlays. ${ }^{54}$ It next ascertains how much cash is required as a buffer fund to supplement collections on that day (or those days) of the month when collections lag most behind disbursements or least anticipate them. This safety margin is the second item to be considered in determining working

cinnati, 75 P.U.R. (N.S.) 97, 105-6 (Ohio 1948) (1/8 annual operating expenses plus 1/24 purchased power); Pacific Tel. \& Tel., 75 P.U.R. (N.S.) 379, 399-401 (Cal, 1948) (2.17\% annual expenses excluding depreciation); West Palm Beach Water Co. v. West Palm Beach, P.U.R. 1930A 177, 194-7 (S.D. Fla. 1929) (3 months).

51. Norfolk v. Chesapeake \& Potomac Tel. Co. of Virginia, 192 Va. 292, 306, 64 S.E.2d 772, 780 (1951) ; Chesapeake \& Potomac Tel. Co., 84 P.U.R. (N.S.) 175, 193 (Md. 1950) ; Interstate Power Co., 2 F.P.C. 71, 85-6 (1939); Long Island Lighting Co., 18 P.U.R. (N.S.) 65, 157-65 (N.Y. 1935) (differed for each item of expense).

52. Northampton \& B.R.R., 149 I.C.C. 244, 263-72 (1928); see also Atchison, T. \& S.F. Ry., 127 I.C.C. 1, 77-88 (1927). For an explanation of the ICC method (called the "Field" method after the member of the Commission who developed it) by one who was a Commissioner at the time that it was developed, see Stecher, The Determination of Working Capital in Railroad and Public Utilities Valuations, 39 Y ALE L.J. 927 (1930). The explanation which follows draws very heavily on these two cases and this Article. See also III-A Sharraran, op. cit. supra note 10 . Note also that the ICC method grants an allowance for materials and supplies in addition to the cash allowance here described. For the ICC method of computing materials and supplies, see text at note 77 infra.

53. See Sohio Western Pipelines, Inc., 51 Val. Rep. I.C.C. 846, 859 (1951).

54. Whenever the cash received for service performed in any particular period lags behind taxes (for a discussion of the propriety of including taxes, see text following note 82 infra) and the outlays incurred in connection with service performed in that period, capital needed for operating purposes is the amount by which the outlays and taxes falling due exceed the amount currently received as reimbursement for operating expenses. (This computation excludes from current receipts that portion attributable to net operating income, i.e., the amount to be returned to investors in the form of interest or dividends, or reinvested in additions and betterments, or used for corporate purposes other than the rendering of carrier service.) In order to compute the amount of this invested cash, the commission determines from the carrier's operating statistics for a representative period of time, usually three years, the amount of cash received from various sources in payment for its carrier service and the weighted average elapsed time from the beginning of such service to the receipt of the cash in the treasury. The amount of cash paid out for various purposes in connection with carrier service and taxes, and the weighted average elapsed time from the beginning of such service until the payments are made are also ascertained for the same period. Next, comparing the average delay in the receipt of all cash and the average delay in the making of all payments, the com- 
capital. ${ }^{55}$ The amount of the allowance will be composed of the daily average amount needed to raise lagging receipts to meet accruing payments (if receipts lag behind payments), and the amount needed to enable the company to maintain a buffer fund on those days when accumulated receipts lag most behind (or least exceed, if the receipts generally exceed payments) accumulated payments falling due.

While this method considers to some degree both the requirements and the sources of the utility's funds, its use is limited because of the different standards and methods employed in rate making by the Interstate Commerce Commission and the public utility regulatory bodies. Rates charged by carriers regulated under the Interstate Commerce Act are established by the carrier and are subject to attack only if they are unjust, unreasonable, or discriminatory. ${ }^{56}$ Utility rates, however, must be approved before they become effective and must be sufficient to furnish the investors with a fair return on the fair value invested in used and useful property. The ICC method does not consider sources other than customer receipts in determining the necessity for granting an allowance. If the company's requirements could be met through borrowing from banks or obtaining credit from suppliers, the ICC would still grant an allowance, so long as these bills could not be met through accumulated

mission ascertains whether the cash was received in hand, on the average, ahead of the maturity of payments to be made, or whether payments had to be made for a period before the cash receipts reached their full current volume. In either case the commission studies the number of days by which cash recepits anticipated or lagged behind the due dates of payments. If the receipts anticipated payments, the number of days preceding payment multiplied by the average daily amount paid gives for the three year period the average amount of cash received applicable to payments in excess of the payments made. If, on the other hand, receipts lagged behind payments, the number of days of this lag multiplied by the average daily amount gives the average amount of cash that had to be obtained from some source other than receipts to pay expenses until cash was received in sufficient volume. This latter result indicates the average invested cash used throughout the period to supplement lagging collections in order to meet maturing disbursements connected with carrier operations.

55. Whether payments anticipate or lag behind receipts, the relation between collections and disbursements is not uniform throughout the month. At certain times the collections flow in more slowly than disbursements flow out, and vice versa. The maximum lag or minimum surplus in cumulated receipts applicable to payments is found by comparing day by day the cumulated daily receipts with the cumulated daily payments during the average month's experience and noting on what day the deficiency, if any, was greatest, or the surplus was least. This result indicates by what amount, on the day or days indicated, the receipts in hand had to be supplemented by cash from some other source in order to meet all payments due by such day and still have a safe buffer fund of reserve cash on hand. The size of the buffer fund is determined from a consideration in detail of the frequency with which collections from various sources are made and payments for various purposes are disbursed and of the stability of such a composite inflow and outflow. The commission, in determining the proper size of the buffer fund, considers business practices which large numbers of individuals concurrently follow. Northampton \& B.R.R., 149 I.C.C. 244, 268 (1928). This amount of invested cash may never all be paid out, and at certain times of the month may all be on hand. But whatever part is not paid out must be kept on hand to cover the peak requirements of each month with an adequate margin of safety. If there is no lag in receipts on any day of the month, then no cash working capital is used to supplement receipts in meeting payments, although an investment in cash working capital may be used to maintain a sufficiently protective buffer fund at all times.

56. 24 STAT. 384 (1887), as amended, 49 U.S.C. § 15 (1946). 
receipts from customers. If the purpose of a working capital allowance is to reimburse investors for the use of their funds, no allowance should be granted when the requirements can be met from these other sources, as is discussed below. ${ }^{57}$ Also subject to criticism is the concept of the buffer fund, which is an integral part of the ICC method. Under the ICC method, an allowance is made to permit the company to maintain at all times enough cash to meet peak requirements at certain times during the year. The definition of what constitutes a "safe" reserve leaves much in doubt, and amounts at best to a considered guess based on a comparison with the rest of the industry. A large buffer fund actually kept on hand may indicate inefficient managerial application of funds. Consequently, the ICC method allows little commission control over managerial practices and may reward lax and inefficient management.

Other methods for determining the proper allowance have been suggested, including the use of a fixed percentage of the rest of the rate base, ${ }^{68}$ and even a fixed percentage of operating revenues. ${ }^{59}$ Neither of these methods takes into consideration either the requirements of the company or the sources of the funds; they are justifiable methods only where practical considerations prevent any other study or method of computation, and only if their limitations are clearly recognized. ${ }^{60}$

\section{Materials and Supplies}

Regardless of the theory by which they compute the cash working capital allowance, the regulating commissions have tended to base their determination of the amount of materials and supplies to be included in the rate base ${ }^{61}$ on the actual inventory carried by the utility. Commissions

57. See text following note 105 infra.

58. Washington Public Serv. Comm'n v. Interstate Tel. Co., CCH 1953 State UTIL. LAW REP. $\llbracket 16449.04$ (Wash. 1952) (10\% net plant in Washington); Washington Public Serv. Comm'n v. Pacific Tel. \& Tel. Co., CCH 1950 StATE UTII. LAW REP. I15985.02 (Wash. 1951) (2\% average net plant); Washington Public Serv. Comm'n v. Pacific Tel. \& Tel. Co., 85 P:U.R. (N.s.) 204, 209-10 (Wash. 1949) (2\% average net plant); Tri-County Tel. Co., P.U.R. 1930A 348, 351 (Mich. 1929) (5\% physical assets).

59. Southwestern Tel. \& Tel. Co., P.U.R. 1915E 1087, 1098 (Mo. 1915) (1/12 gross annual income).

60. See California Water and Tel. Co., CCH 1953 State Utm. LAW Rep. I1 16466.06 (Cal. 1952) (uses percentage of operating revenues since lag study only lately used and only for large companies); Washington Public Serv. Comm'n v. Pacific Tel. \& Tel. Co., CCH 1953 STAte UTIL. LAw ReP. $\Uparrow 15449.03$ (Wash. 1952) (accepts percentage of net plant in absence of proof that portion of operating expenses represents the Washington needs); New. England Tel. \& Tel. Co., CCH 1947 STATE UTIL. LAW REP. $\mathbb{1} 15122.04$ (Me. 1947) (rejects percentage of capital investment as basis).

61. Of approximately 150 cases studied, only one was discovered in which the materials and supplies allowance was combined with the working cash computations and alternative sources offset against the requirements for such supplies. Southern Bell Tel. \& Tel. Co., 96 P.U.R. (N.S.) 1, 13 (Ala. 1952). Cf. Washington Public Serv. Comm'n v. Pacific Tel. \& Tel. Co., 85 P.U.R. (N.S.) 204, 209 (Wash. 1949) (considered as a requirement along with working cash, but no offsetting involved). Only a few questioned the size of the inventory carried by the company; e.g., Southern Bell Tel. \& Tel. Co., 92 P.U.R. (N.S.) 335, 360 (Fla. 1952) (excludes amount for construction); Cascade Town Co., 80 P.U.R. (N.S.) 102, 109 (Colo. 
variously use inventory on hand at the end of the period, ${ }^{62}$ at the beginning of the period, ${ }^{63}$ average beginning and ending balances, ${ }^{64}$ inventory on hand and paid for, ${ }^{65}$ average investment, ${ }^{66}$ average monthly balance of the inventory account increased for present prices, ${ }^{67}$ average inventory over a. period of years, ${ }^{68}$ a "reasonable" inventory, ${ }^{69}$ inventory necessary to take care of peak demands, ${ }^{70}$ percentage of net plant in the state ${ }^{71}$ or

1949) (no evidence presented by company) ; Public Serv. Comm'n v. Great Northern Util. Co., P.U.R. 1929B 176, 197 (Mont. 1929) (amount on hand not conclusive). One commission even said that the case before them involved the first time anyone asked to exclude the materials and supplies allowance, and that the overwhelming weight of authority opposed such an approach; they accordingly granted the allowance without analysis of its need. Chesapeake \& Potomac Tel. Co. of Virginia, 85 P.U.R. (N.S.) 435,472 (Va. 1950). They were affirmed by the Virgina Supreme Court of Appeals on the ground that the allowance was reasonable. Norfolk v. Chesapeake \& Potomac Tel. Co. of Virginia, 192 Va. 292, 306, 64 S.E.2d 772, 780 (1951). See also Southwestern Bell Tel. Co., CCH 1953 State UtIL. LAw Rep. If 16557.02 (Ark. 1953), disallowing working capital because of federal tax accruals, but refusing to "encourage or prevail upon a utility to finance materials and supplies with funds supplied by tax accruals." Id. at $\Uparrow 16557.02$. Cf. cases cited in Stecher, supra note 10 , at 940 n.53.

62. E.g., Hartford Elec. L. Co., 95 P.U.R. (N.s.) 161, 167 (Conn. 1952) ; Public Serv. Co. of New Hampshire, 92 P.U.R. (N.S.) 443, 463 (N.H. 1951); Pittsburgh v. Pittsburgh Ry., $29 \mathrm{~Pa}$. P.U.C. 778, 785 (1951); Indiana Ass'n Tel. Co., 88 P.U.R. (N.S.) 196, 201 (Ind. 1950); Lincoln Tel. \& Tel. Co., 82 P.U.R. (N.S) 33, 37 (Neb. 1950); Chesapeake \& Potomac Tel. Co., 82 P.U.R. (N.S.) 498, 507 (W. Va. 1949); Detroit v. Panhandle Eastern Pipe Line Co., 3 F.P.C. 273, 283 (1942).

63. E.g., Pennsylvania PUC v. Scranton-Spring Brook Water Serv. Co., $28 \mathrm{~Pa}$. P.U.C. 424, 445 (1950) semble. (1950)

64. E.g., Greensburg v. Peoples Natural Gas Co., 29 Pa. P.U.C. 181, 191

65. E.g., Chesapeake \& Potomac Tel. Co. of West Virginia, 89 P.U.R. (N.S.) 250,259 (Ẅ. Va. 1951).

66. E.g., Mississippi River Fuel Co., 95 P.U.R. (ख.s.) 435, 445 (FPC 1952) (disapproving average ending balance); Pacific Tel. \& Tel. Co., 93 P.U.R. (N.S.) 1,5 (Ore. 1952) ; Pennsylvania PUC v. Duquesne Light Co., 29 Pa. P.U.C. 674, 695 (1951) ; Pennsylvania W. \& P. Co., 8 F.P.C. 1, 76 (1949); Bell Tel. Co. of Nevada, 82 P.U.R. (N.s.) 529, 538 (Nev. 1949); Salt Lake City Lines, CCH 1947 State Utrl. LAW Rep. II 15594.02 (Utah 1949); Central Vermont Public Serv. Corp., 82 P.U.R. (N.S.) 601, 610 (Vt. 1949) ; Cincinnati G. \& E. Co. v. Cincinnati, 75 P.U.R. (N.S.) 97, 105-6 (Ohio 1948); Puget Sound Navigation Co., CCH 1947 State U'ril. Law Rep. I 15152.04 (Wash. 1947); Worcester Elec. I. Co. v. Attwill, P.U.R. 1929B 1, 62 (D. Mass. 1929).

67. E.g., Philadelphia v. Pennsylvania PUC, Opinion of PUC, Dec. 23, 1952 (unreported).

68. E.g.y Wisconsin Tel. Co., 80 P.U.R. (N.s.) 482, 497 (Wis. 1949) (5 years); Fleisher v. Harrisburg Suburban Water Co., 29 Pa. P.U.C. 302, 313 (1951) (5 years, which was about equal to the ending balance).

69. E.g., Norfolk v. Chesapeake \& Potomac Tel. Co. of Virginia, 192 Va. 292, 306, 75 S.E.2d 772, 780 (1951) ; Illinois Central R.R., 89 P.U.R. (N.S.) 192, 214 (IIl. 1951) ; Monmouth Consol. Water Co., 81 P.U.R. (N.S.) 38, 41 (N.J. 1949); Cleveland Elec. Illum. Co. v. Cleveland, 67 P.U.R. (N.S.) 65, 83 (Ohio 1947); Chicago District Elec. Generating Corp., 2 F.P.C. 412, 424 (1941); Great Western Power Co., P.U.R. 1923C 545, 565 (Cal. 1923).

70. E.g., West Palm Beach Water Co. v. West Palm Beach, P.U.R. 1930A 177, 196-7 (S.D. Fla. 1929).

71. E.g., Washington Public Serv. Comm'n v. Interstate Tel. Co., CCH 1953 STATE UTIL. LAW REP. I16449.04 (Wash. 1952) (10\% net plant in Washington); Washington Public Serv. Comm'n v. Pacific Tel. \& Tel. Co., CCH 1950 STATE UTIL. LAW REP. T15985.02 (Wash. 1951) (2\% net plant); Washington Public Serv. Comm'n v. Pacific Tel. \& Tel. Co., 85 P.U.R. (N.S.) 204, 210 (Wash. 1949) (2\% net plant). 
simply what is necessary in the company's judgment and experience. ${ }^{72}$ Some commissions deduct from this figure the amount of supplies on hand held for construction work in progress, ${ }^{73}$ others deduct the amounts contributed by customers. ${ }^{74}$ Still others add enough of an allowance to permit the carrying of various supplies of coal and other raw materials, ${ }^{75}$ and enough to meet emergencies. ${ }^{76}$ The ICC method studies the average balances for the past five years, deducting most of the scrap included in those inventories, and excluding the amount of inventory held for imminent use already charged to operating expense, and further deducting stock for subsequent use in additions, betterments or reconstruction or held for supplying other concerns. It then determines the percentage relationship which this adjusted average amount bears to the average operating expenses for the same period, adjusts the percentage to accord with the trend of rising or falling prices, and applies the adjusted percentage to the operating expenses included in the rate study in order to determine the amount of materials and supplies to be included along with the working cash allowance. ${ }^{77}$ There is no apparent reason for treating this required expenditure for materials and supplies differently from any other necessary cash outlay. The amount of the allowance, if any, should be computed in accordance with the principles set out below as applicable to the entire working capital computation.

\section{Suggested Refinement of Expense Approach}

In searching for a more rational and exacting method of computing the working capital allowance, the two possible functions of such an

72. E.g., California Water \& Tel. Co., CCH 1953 STATE UTIL. LAW REP. I1 16466.06 (Cal. 1952) (normal level); Southwestern Bell Tel. Co., 87 P.U.R. (N.S.) 97, 111 (Ark. 1951); Hackensack Water Co., CCH 1947 STATE UTI. LAw REP. \15690.01 (N.J. 1949); Auto Livery Co., P.U.R. 1915E 1, 4 (D.C. 1915); Barnett Taxicab Co., P.U.R. 1915E 6, 8 (D.C. 1915) ; Terminal Taxicab Co., P.U.R. 1915B 546, 551 (D.C. 1915). Cf. Pennsylvania PUC v. Royal-Allison Water Co., 29 Pa. P.U.C. 509, 521 (1951) (none asked since no inventory carried) ; ArkansasLouisiana Gas Co., CCH 1953 STATE UTIL. LAW REP. đ16428.07 (Ark. 1952) (allowed although testimony not sufficient); Ohio Bell Tel. Co., 82 P.U.R. (N.S.) 341, 348-9 (Ohio 1949) (commission's estimate); Public Serv. Comm'n v. Great Northern Util. Co., P.U.R. 1929B 176, 197 (Mont. 1929) (not conclusive).

73. E.g., Rochester G. \& E. Co., CCH 1950 State UTIL. LAw REp. $\| 16164.01$ (N.Y. 1952); Southern Bell Tel. \& Tel. Co., 92 P.U.R. (N.S.) 335, 360 (Fla. 1952); Western Colorado Power Co., P.U.R. 1918E 629, 644 (Colo. 1918). Cf. Cincinnati \& Suburban Bell Tel. Co., CCH 1953 State Utin. Law REP. 116485.03 (Ohio 1953); Commonwealth Water Co., 6 N.J. Public Util. Comm'r Rep. 662 (1918) (not deducted because interest during construction can't be capitalized). See BAUER AND Gold, op. cit. supra note 7, at 294.

74. E.g., Southwestern States Tel. Co., 94 P.U.R. (N.S.) 97, 103 (Ark. 1953).

75. E.g., Pennsylvania PUC v. Duquesne Light Co., 29 Pa. P.U.C. 674, 695 (1951) (90 days) ; Cleveland Elec. Illum. Co. v. Cleveland, 67 P.U.R. (N.s.) 65, 84 (Ohio 1947) (reasonable coal supplies); Worcester Elec. L. Co. v. Attwill, P.U.R. 1929B 1, 62 (D. Mass. 1929) (several months' coal supplies).

76. E.g., West Palm Beach Water Co. v. West Palm Beach, P.U.R. 1930A 177, 196-7 (S.D. Fla. 1929).

77. Northampton \& B.R.R., 149 I.C.C. 244, 265 (1928); Atchison, T. \& S.F. Ry., 127 I.C.C. 1, 86 (1927). See also Stecher, supra note 10, passim. Even under the ICC method, which does to some degree consider the sources of working cash, there is no consideration of the source of the funds for materials and supplies. 
allowance in the rate base should be the guide. In addition to compensating investors for the use of their money in essential capacities, whether or not invested in productive fixed capital assets, the allowance can be used to encourage efficient managerial use of resources. The allowance should, therefore, take cognizance of both the actual working capital requirements of the utility and the sources available to meet those needs. Applying the lag in payment for services by consumers, offset by the lag in payment for those services by the company, to annual operating expenses (i.e., the expense approach used by some commissions) does not compensate for all of the cash outlays which the company must bear out of its own funds prior to payment by the consumer. Non-expense items, such as minimum bank balances, petty cash funds, and some emergency outlays, necessitate the use of working cash just as does the payment of expenses for rendering services. If the commission is making an exacting time lag study, it should consider these items in the cash requirements. ${ }^{78}$ Some commissions do so by rounding out the actual lag and granting an arbitrary percentage of expenses; ${ }^{79}$ such estimates may bear no relation to the actual requirements. In a truly accurate study all cash outlays, whether or not they are entitled expenses, should be considered in computing requirements. At the same time, if a commission determines that the company should be able to meet its requirements from funds obtained from sources other than investors, the commission should not grant a fair return, but only enough to reimburse the company for the actual cost of these funds. This would encourage management to obtain its funds elsewhere by borrowing from banks or obtaining credit from suppliers, or by changing its billing policies to obtain faster payment from customers.

\section{Working Capital Requirements}

Requirements exist in all utilities in which revenues are received after the liability for providing service has been incurred by the company. Many passenger railroad, street railway, bus, taxi, and ferry companies collect from their customers simultaneously with the rendering of the service (or in advance, as in the case of commutation tickets), at the same time paying their suppliers and laborers periodically after receipt of these supplies and services; they nonetheless have requirements, although they may be entitled to no allowance because the requirements are met by

78. Another item to be considered is the credit standing of the company, with some reference to the balance sheet position. Rates should be high enough so that the company could maintain whatever current (or quick) asset ratio is considered necessary to enable the company to borrow at favorable interest rates. But granting an allowance for working capital does not per se guarantee that a favorable position will be maintained, since the company might pay out the additional revenue in dividends; nor does disallowance necessarily mean that the company will be unable to maintain such a favorable position, since other funds might be available. Therefore, while the balance sheet should be considered, it is not conclusive nor even a major factor in computing the allowance. See Pittsburgh v. Pennsylvania PUC, 370 Pa. 305, 312, 88 A.2d 59, 62 (1952).

79. See cases cited notes 47-51 supra. 
current receipts from customers. ${ }^{80}$ Other utilities bill largely, if not completely, after liabilities have been incurred. For example, metered gas, electric, and water companies cannot read their meters until after the gas, electricity, and water is produced and delivered; long-distance toll telephone calls are billed only after the calls are completed; there is even a lag in collection of coins from coin boxes for calls which are paid for simultaneously with the rendering of the services. Some electric, gas, water and telephone utilities partially offset these requirements by rendering estimated bills in advance, with a periodic reading of meters and adjusting of accounts. To the extent that customers pay after the utility incurs the liabilities, the utility must bear the cost of services through use of its working capital until corresponding revenues are obtained. To the extent that customers pay in advance, no working capital is needed to pay for those services; in fact, stich advance payments may even constitute a source of funds temporarily available to offset any other working capital requirements. As one commission explained:

"There are two general categories of expenses. The first category includes items of expense which have to be paid before corresponding revenues are received. As to other items of expense, particularly Federal Income Taxes, corresponding revenues are received far in advance of the dates when the taxes become due and payable to the Government. The first category of expenses gives rise to a Cash Working Capital requirement: With respect to the second category of expenses, it should be noted that the customer actually provides funds considerably in advance of the date when these expenses must be paid. If the funds so provided are generally in excess of the cash required to meet the first category of expenses then the investors are not required to furnish cash working capital." 81

The commission here is contending that working capital requirements are measured by the time elapsed between the date of payment for goods and services by the company and the date of payment for those goods and services by the consumer. Using the commission's analysis, no

80. See Illinois Central R.R., 89 P.U.R. (N.s.) 192, 214 (IIl. 1951) ; Massachusetts Northeastern Trans. Co., 86 P.U.R. (N.s.) 192, 196-97 (Mass. 1950); Salt Lake City Iines, CCH 1947 STATE UTIL. LAw REP. II 15594.02 (Utah 1949); Rochester Transit Corp., 72 P.U.R. (N.S.) 455, 466 (N.Y. 1948); Nashville Ry. \& L. Co., P.U.R. 1929A 664, 677 (Tenn. 1928).

Sometimes commission studies have indicated that such utilities do need some working capital allowance. See, e.g., Philadelphia Trans. Co v. Pennsylvania PUC, $155 \mathrm{~Pa}$. Super. 9, 29, 37 A.2d 138, 147 (1944); Southern Bell Tel. \& Tel. Co., 92 P.U.R. (N.S.) 335, 360 (Fla. 1952) ; Pittsburgh v. Pittsburgh Ry., 29 Pa. P.Ü.C. 778, 785-6 (1951); Chesapeake \& Potomac Tel. Co., 82 P.U.R." (N.s.) 498, 506 (W. Va. 1949); Auto Livery Co., P.U.R. $1915 \mathrm{E}$ 1, 5 (D.C. 1915) ; Terminal Taxicab Co., P.U.R. 1915B 546, 551 (D.C. 1915). Cf. Pittsburgh v. Pennsylvania PUC, $168 \mathrm{~Pa}$. Super. 95, 103, 78 A.2d 35 (1951) ; Pennsylvania PUC v. Johnstown Traction Co., CCH 1947 State UTIL. LAW Rep. 1548.01 (Pa. 1948) (allowances granted without inquiry into need). 1949).

81. Hackensack Water Co., CCH 1947 State Util. LAW REP. $\Uparrow 15690.01$ (N.J. 
requirements would exist if a company received its goods and services on credit equal to the lag in consumers' payments, but a requirement would exist if the company had to pay cash to its suppliers, even though the commission might grant no allowance in the second case if alternative funds were available. Under our definition, however, a requirement would exist in both instances, since economically they represent the same situation. But no allowance would be granted in the first case because there are available alternative sources of funds not supplied by investors - that is, credit extended by suppliers. In the second case no allowance would be granted if alternative sources are available, such as loans extended by banks, accrued taxes collected in advance from customers, etc., as discussed below.

The first step in computing the proper allowance in the rate base is thus to select the current expenses and other cash outlays which must be met from the utility's own cash. There are three categories of cost items to be recovered in the utility's income, in addition to the fair return to its investors: a provision for depreciation, retirement and obsolescence; taxes; and operating expenses. ${ }^{82}$ The annual provision for depreciation does not involve an outlay of cash, but represents merely a restriction of surplus designed to allocate the cost of an asset over the accounting periods which it benefits. The same is true of provisions for retirement and obsolesence. These three items do not, therefore, give rise to a working capital requirement. Since liability for state and federal operating taxes is incurred by the company long after funds for such taxes are supplied by customers, the taxes do not give rise to a working capital requirement. Moreover, the cash collected for these taxes in advance of the due date, until it must be paid over to the government, supplies a source of funds to meet other requirements.

The third category of cost is the annual operating expenses. Some of these are paid for by the company in advance of receipt of revenue; however, even among those paid in advance, there are some expenses which do not properly give rise to a working capital requirement. Nonrecurring items, such as emergencies and contingencies, while appropriate expenses for which the company must make an outlay, may be too speculative to be included in the anticipated working capital requirements. ${ }^{83}$ If, however, they recur with enough regularity to be estimated accurately for the purpose of computing requirements, they can no longer be properly

82. BARNes, op. cit. supra note 1 , at 315 .

83. See Mississippi River Fuel Co., 4 F.P.C. 340, 345 (1945) ; accord, Pennsylvania W. \& P. Co., 8 F.P.C. 1,74 (1949) (too vague); Pennsylvania PUC v. George, 28 Pa. P.U.C. 1, 14 (1949) (would amount to capitalizing operating losses); Detroit v. Panhandle Eastern Pipe Line Co., 3 F.P.C. 273, 283 (1942) (would be duplication). Cf. Philadelphia Trans. Co. v. Pennsylvania PUC, $155 \mathrm{~Pa}$. Super. 9, 29-30, 37 A.2d 138, 147 (1944); Worcester Elec. L. Co. v. Attwill, P.U.R. 1929B 1, 62 (D.C. Mass. 1929) (allowance for emergencies granted). BarNes, op. cit. supra note 1 , at 496 , suggests that temporary borrowings can be utilized to meet emergencies. It is again important to note that rejecting the requested allowance for working capital to meet emergencies will not impair the utility's ability to meet those emergencies. See note 28 supra. 
termed "emergencies" or "contingencies" and should then be included among the customary factors leading to a requirement. ${ }^{84}$ Some items, such as purchased gas, are bought by the utility for retailing to the consumer and are paid for in advance by the consumer. They should not represent allowable expenses in calculating requirements, since the utility acts merely as a conduit for the consumers' payments to the actual suppliers of the gas. Such items are not paid out of current funds. ${ }^{85}$ Prepayments, such as prepaid insurance, should be included as an allowable expense if they must be made out of current funds. ${ }^{86}$

The remaining categories of operating expenses all constitute items for which cash outlays must be made by the company. In order to determine the dollar amount of these outlays, however, discounts available to the company should be considered. Suppliers and creditors customarily stipulate a period of time (usually 10 days) after the expense is incurred during which the utility may take a discount in their payment, while giving the utility a month in which to pay the net bill. If the management determines that it is economically feasible and cheaper to pay the discounted bill within 10 days and the commission finds this determination reasonable, then the total requirements will have to be reduced by the amount of the total discounts taken during the year. ${ }^{87}$ In addition, since the utility is waiting as much as 10 days before making the discounted payment, the credit thus being. taken advantage of will be available as another source to offset its requirements, as would be true of the entire undiscounted amount should the company decide to wait the full 30 days. ${ }^{88}$

Three items not included among the utility's expenses for the year might represent requirements for working cash. The first of these is the

84. The argument could be made that a "cushion" is needed to protect the company against even unforeseeable emergencies which are not ordinarily provided for in the operating expenses. For example, at one point in 1952 the Philadelphia Transportation Company found that its cash balances had dwindled to less than $\$ 507,000$. Brief for Philadelphia Transportation Co., Intervenors, p. 11, Philadelphia v. Pennsylvania PUC, 173 Pa. Super. 38, 95 A.2d 244 (1953). An ordinarily unforeseeable emergency such as a strike or a heavy snowstorm at that time would have been disastrous. But an additional allowance for working capital is not necessarily called for even in such a situation. As pointed out in note 28 supra, the allowance would not affect managerial policy as to billing practices or dividend payments; thus, there would be no assurance that the company would have on hand any greater cash funds during the ensuing year than they had previously without the allowance. Also, if the company found itself in such straitened circumstances and an emergency did occur, it could borrow from a bank, even if it had to pay higher interest rates. The company in its next rate hearing would then have a more persuasive argument for including such an emergency as an operating expense in the future.

85. See cases cited note 44 supra.

86. See Pennsylvania PUC v. Pennsylvania Tel. Corp., 28 Pa. P.U.C. 646, 688-9 (1950); Penn-York Natural Gas Co., 5 F.P.C. 33, 36 (1946); see BARNes, op. cit. supra note 1 , at 498 . Cf. Pfeifle v. Pennsylvania P. \& L. Co., 57 P.U.R. (N.S.) 1, 24 (Pa. 1945) (portion of prepayments excluded since already included in operating expenses); Worcester Elec. L. Co. v. Attwill, P.U.R. 1929B 1, 62 (D. Mass. 1929) (include prepayments while using balance sheet method).

87. This accords with general accounting practice among utilities, which include the discounted amounts in computing their operating expenses.

88. See text at note 128 infra. 
minimum balances which must be kept in banks in order to prevent being charged a service fee. Minimum bank balances should not, however, be included among the utility's cash requirements if the utility customarily maintains or acts as depository of an equivalent amount of funds such as sinking funds for retirement of bonds, segregated funds for payment of various debts (such as income or social security taxes), or customers' deposits. Such funds, even if they must be kept liquid are thus not available for offsetting other requirements as suggested below, ${ }^{89}$ may be kept in the bank to maintain the required balance, ${ }^{90}$ thus freeing the company's own cash for productive purposes. A requirement would exist, although no allowance should be made, even if such funds are not available, if it would be cheaper to the consumer for the utility to pay the service charge levied by the bank, or to obtain a loan at interest from a parent company or bank, than for the utility to use investors' funds to maintain those balances and collect from the consumer a fair return on that amount. ${ }^{91}$ The service charge or interest on the loan should be included in operating expenses and recovered from rates, although apparently they are not so treated presently.

The second non-expense item which may give rise to a working capital requirement is the petty cash which must be kept on hand in order to make change for customers or to meet minor emergency expenses. ${ }^{92}$ The third non-expense item which gives rise to a working capital requirement is an amount for the maintenance of an inventory of materials and supplies used in the production of the product being sold by the utility or used to keep the utility in repair. ${ }^{93}$ Almost without exception commissions and courts treat this item separately from cash working capital; even those jurisdictions rejecting the balance sheet method have followed a method of determination based on the actual inventory carried by the utility. ${ }^{94}$ There is no doubt that utilities require some inventory of materials and supplies to keep operating efficiently; there is little justification, however, for treating the item separately from the rest of the working

89. See text following note 106 infra. Of course, either use of these funds would be possible only if their commingling is not precluded by a trust agreement or law.

90. New York Tel. Co., 84 P.U.R. (N.s.) 267, 276 (N.Y. 1950); Michigan Consol. Gas Co., 79 P.U.R. (N.S.) 445, 449 (Mich. 1949) ; Pfeifle v. Pennsylvania P. \& I. Co., 57 P.U.R. (N.S.) 1, 23-4 (Pa. 1945); Interstate Natural Gas Co., 3 F.P.C. 416, 425-6 (1943); Cities Service Gas Co., 3 F.P.C. 459, 478 (1943); Canadian River Gas Co., 3 F.P.C. 32, 52 (1942). Accord, Cleveland Elec. Illum. Co. v. Cleveland, 67 P.U.R. (N.s.) 65, 83 (Ohio 1947) (excluded since evidence of necessity not conclusive).

91. See cases cited note 46 supra.

92. E.g., Public Serv. Co. of New Mexico, 84 P.U.R. (N.S.) 451, 453 (N.M. 1950). Cf. Colorado Springs L.H. \& P. Co., P.U.R. 1916A 872, 882 (Colo. 1915). Also, one of the factors to be considered here is the credit position of the company and the necessity of a favorable balance sheet position in order to promote continuing ability to borrow cheaply. See Pittsburgh v. Pennsylvania PUC, 370 Pa. 305, 314, 88 A.2d 59, 64 (1952).

93. See BARNES, op. cit. supra note 1, at 495, 498; see also Jacksonville Gas Co. v. Jacksonville, 82 P.U.R. (N.s.) 67, 80 (Fla. 1949).

94. See note 61 supra. 
capital computation. Computation of this allowance based on actual inventory is attended by the same fallacies as a similar computation of cash working capital needs, ${ }^{95}$ since not all inventory need be supplied by investors' funds. The most consistent method would seem to be to include the materials and supplies item as one of the allowable outlays giving rise to a working capital (used in the generic sense) requirement. The amount to be included in the requirements would be based on a reasonable inventory sufficient to meet anticipated future needs, determined by a study of past requirements and excluding emergency needs ${ }^{96}$ for the same reason that emergency requirements should be excluded from cash requirements. ${ }^{97}$ There would be no need to deduct amounts contributed by customers, as some commissions do, ${ }^{88}$ since they would be taken into consideration in determining sources of funds for meeting all working capital needs. ${ }^{99}$ Whether supplies for construction work in progress or future construction ${ }^{100}$ are to be included would depend on whether an allowance for such construction work in progress is made in another part of the rate base; if the item does appear elsewhere in the rate base, to allow a fair return on that portion of materials and supplies would amount to capitalizing it twice. ${ }^{101}$

Computing the Amount of Requirements:- Having determined the categories of expenses and outlays to be considered as working capital requirements, it is then necessary to compute the dollar amount of these requirements. The yearly total of all of the expenses and outlays which must be paid by the company prior to the receipt of income is divided by 365 , resulting in the company's average daily outlay. It is then necessary to make a study of the company's billing practices to determine the average days of lag in collection of receipts from customers for services rendered. Suppose that a telephone company bills some of its customers, representing $52 \%$ of its total operating revenues, on the average 15 days in advance of the date that the service is rendered; that the bills are not received by the customers for 7 days, and that the customers pay for those services 19 days after receiving the bills; this means that the customers are paying for the services 11 days after the services are rendered; hence payment for $52 \%$ of the billed charges are received 11 days after service rendered. When multiplied by $52 \%$, this gives 5.7 weighted average days. The company bills other

95. See text at note 36 supra.

96. See note 76 supra.

97. See text at note 83 supra.

98. See note 74 supra.

99. See text and note 127 infra.

100. See note 73 supra.

101. See discussion in Cincinnati \& Suburban Bell Tel. Co., CCH 1953 State UTIL. LAW REP. $\mid 16485.03$ (Ohio 1953), which granted an allowance for materials used in construction, since the Uniform System of Accounts prescribed by the Federal Communications Commission and adopted by the Ohio Public Utilities Commission does not permit the company to capitalize interest on any of the property in materials and supplies; hence, if it were eliminated from the rate base the company would be denied a right to earn any return on that amount. 
customers, representing $40 \%$ of its total operating revenues, on the average 15 days after the service is rendered; the bills are not received for several days, and are not paid until a total of 41 days have elapsed from the time of service. This means that 16.4 weighted average days (40\% times 41 days) have elapsed. Also the company collects from its coin boxes on the average 14 days after the calls are made; coin box collections represent $8 \%$ of the company's total collections; the weighted average is 1.1. Adding these weighted averages together gives a total of 23.2 days lag in total collections from date of service being rendered. This indicates that on the average the company must bear 23.2 days' expenses before it receives reimbursement for those expenses from customers. During this time the company must itself bear the liabilities of producing services; multiplied by one average- day's portion of total yearly expenses, it represents the average working capital requirements of that utility.

\section{Sources of Working Capital}

The commission's next task is to determine the sources of funds from which the utility may obtain the out-of-pocket working capital funds. At least six potential sources are available to utilities: current collections from customers in advance of incurring of liability for the services by the utility (the second category of expenses mentioned above) ; ${ }^{102}$ credits extended to the utility in the ordinary course of business by suppliers, creditors and employees; bank loans; loans or advances from parent or affiliated companies; unapplied cash earmarked for sinking funds and other purposes; and cash supplied by investors (either directly as proceeds from the sale of securities or indirectly from the reinvestment of corporate earnings). Only the last of these six sources represents funds on which the utility should be permitted to earn a fair return. ${ }^{103}$ On the amounts which can be obtained from creditors, banks, or parent companies, the utility should be reimbursed for the actual cost of borrowing. ${ }^{104}$ The theory which requires the offsetting of these various sources against the company's working capital requirements and grants an allowance only on the amount which must be supplied from investors' funds, is known as the "alternative funds" method of computation. ${ }^{105}$

One of the most substantial of the alternative sources of funds (but one which has only within the last decade been tapped to any great extent)

102. See note 81 supra.

103. See note 4 supra. See also Southern Bell Tel. \& Tel. Co., 96 P.U.R. (N.s.) 1, 13 (Ala. 1952); Mountain States Tel. \& Tel. Co., 94 P.U.R. (N.s.) 33, 44 (Colo. 1952); Plains Pipe Line Co., CCH 1953 State UtIl. LAw Rep. $\Uparrow 16420.04$ (Wyo. 1952).

104. Which would generally be less than the fair return. See, e.g., Pittsburgh v. Pennsylvania PUC, $370 \mathrm{~Pa} .305,312,88$ A.2d 59, 63 (1952). But the courts which have disallowed working capital because of ability to borrow at a lesser rate have not made provision for reimbursing the company for the cost of such borrowing. See cases cited note 46 supra. Some such provision would seem equitable.

105. Chesapeake \& Potomac Tel. Co. v. Public Serv. Comm'n of Maryland, 93 A.2d 249, 256 (Md. 1952); see also 48 P.U. FORT. 744 (1951). 
is the federal and state tax accruals which are collected from customers along with the current billings, but are retained by the utility for payment to the government at a much later date. ${ }^{100}$ The potentialities of this source was recognized as early as 1923 in California ${ }^{107}$ and 1935 in New York, ${ }^{108}$ but most commissions which recognized the value of any offsetting merely required these funds to be set aside in bank accounts so as to preclude the need for tying up investors' cash to maintain required bank balances. ${ }^{109}$ The Second World War brought about higher tax rates which, along with the federal government's policy of permitting deferred payments by the company, ${ }^{110}$ enabled the utilities to keep on hand larger supplies of cash for longer periods of time.

Several recent cases ${ }^{111}$ have given authoritative recognition to the availability of these alternative funds for offsetting working capital requirements, with a consequent denial of any working capital allowance. In the Pennsylvania Bell Telephone Company case, ${ }^{112}$ the Pennsylvania Supreme Court affirmed the Superior Court's ${ }^{113}$ disapproval of any such allowance, despite the Public Utility Commission's inclusion in the rate base of a figure for working capital.114 The Supreme Court, while

106. Again note the distinction between operating taxes (such as state shares, gross receipts, franchise, property and income taxes, and federal income, unemployment and insurance contributions taxes) and excise taxes (federal, state and local) mentioned in note 6 supra. Also items such as employees' withholding taxes and employee contributions to social security are available for use for a short period of time. See note 125 et seq. infra.

107. Great Western Power Co., P.U.R. 1923C 545, 565 (Cal. 1923) ; Coast Counties G. \& E. Co., P.U.R. 1924C 415, 422 (Cal. 1923).

108. Iong Island Lighting Co., 18 P.U.R. (N.s.) 65, 164 (N.Y. 1935).

109. E.g., Pfeifle v. Pennsylvania P. \& L. Co., 57 P.U.R. (N.s.) 1, 24 (Pa. 1945); Interstate Natural Gas Co., 3 F.P.C. 416, 425-6 (1943); Detroit v. Panhandle Eastern Pipe Iine Co., 3 F.P.C. 273, 283-4 (1942) ; Canadian River Gas Co., 3 F.P.C. 32,52 (1942).

110. INT. REV. CODE $\S 56(b)(2)$ permits corporations to pay their taxes in four unequal installments in the year when due, thus enabling them to make the final payment nine months after the due date. Taxes for the year $A$ will be paid in March, June, September, and December of year $B$, while they have been collected from customers since January of year $A$. This has been true ever since the Revenue Act of 1924, §270, 43 STAT. 295 (1924); but it is only recently that the rates of taxes have been high enough so that taxes collected in advance of payment to the government have become substantial. For the effect of this postponement see AlabamaTennessee Natural Gas Co. v. FPC, 203 F.2d 494, 498 (3d Cir. 1953); Transcontinental Gas Pipe Line, 94 PU.R. (N.S.) 333, 342 (FPC 1952); Chicopee Mfg. Co. v. Public Serv. Comm'n of New Hampshire, CCH 1953 STATE UTIL. LAW REP. I 16364.04 (N.H. 1953); Pittsburgh v. Pennsylvania PUC, $370 \mathrm{~Pa}$. 305, 312-3, 88 A.2d 59, 63 (1952). But each year since 1950 the size of the first two required installments has been increased; for $195490 \%$ will have to be paid by the second installment. Plans are being discussed to accelerate these payments even more rapidly, and possibly even to require payment on an estimated basis in the year for which the tax is imposed, as is the case in many states. See Bureau of NAtional Affatrs No. 772, Report on The Business Outloor 3 (1953). If such a plan should go into effect, then the importance of the other alternative sources would be emphasized as the companies find themselves with less tax funds available for working capital uses.

111. See note 4 supra.

112. Pittsburgh v. Pennsylvania PUC, $370 \mathrm{~Pa}$. 305, 88 A.2d 59 (1952).

113. 169 Pa. Super. 400, 82 A.2d 515 (1951).

114. 81 P.U.R. (N.S.) 316 (Pa. 1949). 
criticizing the lower court's reliance on a balance sheet approach, reached the same result as the Superior Court by studying the comparative time lag in customers' payments and the company's payments to suppliers, and concluding that the remaining requirements were offset by available unsegregated funds for federal and state income taxes. In another recent case, ${ }^{115}$ the Maine Public Utility Commission, after a careful scrutiny of the items to be included in determining the requirements, found that accrued taxes provided an average cash balance greater than the requirements, and similarly refused any allowance.

The best analysis of the working capital allowance is to be found in the opinion of the Maryland Public Service Commission,,116 approved by the Maryland Court of Appeals, ${ }^{117}$ refusing any working capital allowance to a telephone company on the basis of the "alternative funds" theory. The commission first summarized the needs of the telephone industry in general, pointing out that local toll service is largely billed in advance, unlike other types of utility services which are metered and cannot be measured until the end of the billing period; in fact, even more time must elapse between reading and billing. But since the exhibits in this case demonstrated that not all services were paid for in advance of rendition, the commission determined as a fact that there was a weighted average lag of 23.2 days between the time service was rendered and the time it was paid for. It also determined that the company had, on the average, a weighted favorable lag of 1.8 days in the payment of different classes of its expenses, i.e., that the company paid all its bills on the average 1.8 days after incurring the liability for the various classes of expenses. It also found that the company collected taxes and accrued them until time of payment, with an average of 274.5 days elapsing before payment of these taxes. Multiplying the 274.5 days by the average amount of taxes collected per day, and multiplying the average daily amount of the various expenses by 1.8, and adding together these two sources (credit and taxes paid in advance), the commission arrived at a net dollar-day figure. This combined total was divided by the total amount of expenses; the quotient (which was found to be equal to 67.5 days' average expenses) is the amount which the company has available to offset the lag in receipt of revenue. Subtracting the revenue receipt lag of 23.2 days from the sources which were equivalent to expenses of 67.5 days produced a net revenue receipt lag of minus 44.3 days, ${ }^{118}$ which demonstrated, said the

115. Maine PUC v. Bangor Hydro-Elec. Co., 92 P.U.R. (N.s.) 46 (Me. 1952).

116. Chesapeake \& Potomac Tel. Co., 93 P.U.R. (N.S.) 215 (Md. 1952).

117. 93 A.2d 249 (Md. 1952).

118. Note that the 23.2 days represent a weighted average lag of total collections, while the 67.5 days represent a weighted average lag of total expenses. The two figures are, however, comparable, even though collections include more than merely reimbursement for expenses, since the lag in collections indicates the number of days' expenses which must be borne by the company. The refined method suggested in this Note also reduces the total average $\mathrm{lag}$ in collections to a comparable lag in payment for expenses by multiplying 23.2 times the average daily expenditures which thus represents the average working capital requirements of the company. See text following note 101 supra. 
commission, that the company received money from customers for services rendered before it paid the cost of providing such services. Therefore, no cash working capital allowance was made.

The California Public Utility Commission ${ }^{119}$ has also expressed its approval of the "alternative funds" approach, and the third circuit ${ }^{120}$ has stamped its approval on the Federal Power Commission's ${ }^{121}$ adoption of the method. Yet, despite this marked trend toward more searching investigation of the facts behind each requested working capital allowance, there has been a decided reluctance expressed by some commissions and courts ever to disallow completely all working capital in the rate base; some have merely cut the allowance despite an expressed recognition of the complete lack of need for such an allowance. ${ }^{122}$ Other courts and commissions have expressed the fear of disastrous consequences should they encourage the use as working capital of funds such as accrued taxes for which, they say, the company is acting merely as a collection agency. ${ }^{123}$ This attitude ignores the practical fact that the setting aside of accruals is merely a bookkeeping device; the funds are actually mingled and used (or can be without the slightest danger) for operating requirements while a reserve is set aside on paper for these debts so that when they come due they can be paid.

The logic which requires federal tax accruals to be offset against working capital requirements compels the same result in the case of any other payments received from customers or employees in advance of use for their intended purpose. ${ }^{124}$ Payroll taxes withheld from employees, ${ }^{125}$ $1952)$

119. Pacific G. \& E. Co., CCH 1953 State Utir. Law Rep. $\llbracket 16350.06$ (Cal.

120. Alabama-Tennessee Natural Gas Co. v. FPC, 203 F.2d 494 (3d Cir. 1953).

121. 94 P.U.R. (N.S.) 426 (FPC 1952). The FPC had, by this time, adopted this procedure consistently. See cases cited in the circuit court's opinion, AlabamaTennessee Natural Gas Co. v. FPC, supra note 120, at 498.

122. See Western Carolina Tel. Co., CCH 1953 State - UtiL. LAw Rep. $\llbracket 16375.01$ (N.C. 1953); Duke Power Co., CCH 1950 State UTII. LAW REP. \16226.03 (N.C. 1952); New Jersey Bell Tel. Co., 91 P.U.R. (N.S.) 161, 182 (N.J. 1951) (cut, but some allowed); Bell Tel. Co. of Nevada, 90 P.U.R. (N.S.) 287, 291 (Nev. 1951) (token amount allowed) ; Columbus v. PUC of Ohio, 154 Ohio St. 107, 112-13, 93 N.E.2d 693, 697 (1950) (no evidence that receipts in advance were available); New England Tel. \& Tel. Co., 83 P.U.R. (N.S.) 414, 431 (Vt. 1950) (record not clear enough to permit downward revision).

123. See Cincinnati \& Suburban Bell Tel. Co., CCH 1953 State Utr. Law REP. $\llbracket 16485.03$ (Ohio 1953) (wouldn't want to force continual borrowing for these purposes); Southern Bell Tel. \& Tel. Co., CCH 1953 State Utr. LAw ReP. $\llbracket 16475.04$ (N.C. 1953) (questions advisability of changing customary policy of allowance because of availability of tax funds); Chesapeake \& Potomac of Virginia, 85 P.U.R. (N.S.) 435, 473 ( $\mathrm{Va}$. 1950) (offsetting some sources, but not federal excise taxes, employee contributions to social security, or state unemployment taxes, etc.); Bell Tel. Co. of Nevada, 82 P.U.R. (N.S.) 529, 537 (Nev. 1949) (might have disastrous effect on operations in adverse years). Cf. Pacific Tel. \& Tel. Co., 75 P.U.R. (N.S.) 379, 400 (Cal. 1948) (offsetting some sources, but not federal excise taxes or employee contributions to social security taxes); New Jersey Bell Tel. Co., 72 P.U.R. (N.S.) 37, 50-1 (N.J. 1947) (offsetting some sources, but not all taxes). 124. As the federal tax laws change (see note 110 supra) these sources will become more important.

125. Pacific G. \& E. Co., CCH 1953 State UtiL. Law Rep. 116350.06 (Cal. 1952); Consolidated Edison Co. of New York, 96 P.U.R. (N.S.) 194, 272 (N.Y. 1952). See also BARNES, op. cit. supra note 1, at 498. 
contributions from both the employer and employee for federal old age and survivors' taxes, ${ }^{126}$ and customers' contributions in aid of construction ${ }^{127}$ would be available as other alternative funds until they are expended for their respective purposes.

Customers and employees are not the only classes of people other than investors who supply alternative funds to the utility. Suppliers and other creditors customarily stipulate a period of time (usually 10 days) after receipt of bills by the utility during which the utility may take a discount in their payment, and permit the net bill to be paid within 30 days. If the company customarily elects to wait the 30 days before paying the bill, this credit will be available to offset against the working capital requirements. ${ }^{128}$ Should the company customarily elect to take a discount by paying within the allotted 10 days, it will be able to reduce its requirements by the amount of the discount, but at the same time the discounted amount will not have to be paid for 10 days, and the resulting credit will be available to offset against its ultimate requirements. Also, utilities are often in a position to obtain loans from banks and from parent or affiliated companies at rates which may compare favorably with the "fair rate" of return which consumers must pay on the working capital allowance. In such a case, it will prove cheaper to the consumer to pay rates which will compensate the utility for the interest it would have to pay on such loans than to pay a "fair return" on a rate base including the working capital allowance. ${ }^{129}$ Thus, working capital requirements might be offset by the amount of loans available to the utility, provided that the commission finds that it will not harm the fiscal or credit position of the company to make those loans, and provided further that the commission makes a separate allowance in the rates sufficient to pay these interest charges, which are presently considered non-operating expenses. ${ }^{130}$ The effect of the computation would therefore be to permit the company to recover the interest it will have to pay on these loans, but not enough to amount to a "fair return." Disallowance of a fair return will encourage the company to make the most efficient use of its resources but will not penalize the investors.

126. Southern Bell Tel. \& Tel. Co., 96 P.U.R. (N.s.) 1, 13 (Ala. 1952); Consolidated Edison Co. of New York, 96 P.U.R. (N.s.) 194, 272-3 (N.Y. 1952) (which also lists several other items withheld from employees to be offset, including automobile insurance, war bond purchases, union dues, Edison Savings and Loan payments, employees' Mutual Aid Society Payments, Associated Hospital dues, and personal insurance payments). See also BARNEs, op. cit. supra note 1 , at 498 .

127. Ibid. See also Alabama-Tennessee Natural Gas Co., 94 P.U.R. (N.s.) 426, 432 (FPC 1952), aff'd, 203 F.2d 494 (3d Cir. 1953).

128. In other words, the company will have a favorable lag to offset against the unfavorable lag caused by late payments made by customers, as described in the text following note 101 supra. See Chesapeake \& Potomac Te1. Co., 93 A.2d 249, 256 (Md. 1952). This is not quite a suggestion for "spending credit;" it is rather a suggestion that available credit be used to postpone requirements.

129. Pittsburgh v. Pennsylvania PUC, $370 \mathrm{~Pa}$. 305, 315, 88 A.2d 59, 64 (1952); accord, Michigan Bell Tel. Co. v. Michigan Public Serv. Comm'n, 332 Mich. 7, 21,50 N.W.2d 826, 832 (1952) (no working capital allowed since supplied by parent company); Mountain States Tel. \& Tel. Co., 94 P.U.R. (N.S.) 33, 44 (Colo. 1952). 130. See text and notes 46 and 91 supra. 
A final alternative source of working capital funds lies in the unapplied funds earmarked for cash sinking funds, ${ }^{131}$ cash set aside for accrued bond interest not yet payable, ${ }^{132}$ reserves for injuries, insurance and other contingencies ${ }^{133}$ maintained by some companies, and customers' deposits. ${ }^{134}$ These are available until actually applied for their respective purposes. All of these represent funds supplied by customers or creditors, not investors, and consequently should not earn a fair return for investors.

The question of whether the surplus and the reserves for depreciation and obsolescence ${ }^{135}$ represent such a reservoir is more troublesome. Such reserves do not represent cash actually set aside, but constitute merely book entries designed to restrict surplus in order to reflect an allocation of the cost of an asset over the period of time for which that asset is beneficial to the utility. This restriction of surplus enables the company to build up a potential source for replacement of that asset when it has finally outlived its usefulness. The argument could be made that such a restriction of surplus means a reduction of the book profits for the year without any outlay of cash or any other decrease in current assets available for working capital, or, in other words, that the reserves are represented in other assets. In short, the debit expense item of depreciation is properly eliminated from consideration as a working capital requirement; ${ }^{136}$ in addition, the credit to reserve for depreciation, having been established by customers' repayments of depreciation each year through their rates, is available to use for working capital requirements. Some courts have accepted this argument and concluded that no allowance should be made for working capital. ${ }^{157}$ Utility accountants would answer that the reserve represents merely a return to the investors of their capital investment; it may be used for any purpose for which other invested cash may be used. If used for the purchase of other assets, it will earn a return in the rate base through those other assets. If, however, it is used for working capital, then it should be entitled to earn a return just as if any other invested funds were so used. In other words, it is supplied by investors,

131. Compare Troxes, op. cit. supra note 1 , at 283. Ordinarily, however, such sinking funds are not available for use since they are restricted by trust indentures.

132. Pacific G. \& E. Co., CCH 1953 State UtIL. Law Rep. $\llbracket 16350.06$ (Cal. 1952). This item, however, rarely appears on the books of utilities.

133. Ibid.

134. Jacksonville Gas Co. จ. Jacksonville, 82 P.U.R. (N.S.) 67, 80 (Fla. 1949); cf. New England Tel. \& Tel. Co., 94 P.U.R. (N.s.) 65, 69 (Me. 1952). See Commonwealth Water Co., 6 N.J. Public Util. Comm'r Rep. 662, 695 (1918), where the commission refused to offset consumer deposits since the company must pay interest on them. Under the proposed method, this latter position would be untenable, since the interest which the company must pay would be reimbursed by customers in their rates.

135. Bell Tel. Co. of Nevada, 90 P.U.R. (N.S.) 287, 291 (Nev. 1951) ; Public Serv. Comm'n v. Great Northern Util. Co., P.U.R. 1929B 176, 196 (Mont. 1929) (reserve for depreciation, surplus, accrued taxes) ; Nashville Ry. \& L. Co., P.U.R. 1929A 664, 682 (Tenn. 1928) (retirement reserve being used for corporate financial purposes, hence available to offset requirements until proved that it is being used for specific purpose for which set aside).

136. See text following note 82 supra.

137. See cases cited note 135 supra. 
not consumers. The same arguments apply to surplus, which constitutes reinvested funds. But if excessive depreciation has been charged over the years, thus building up an excessively high depreciation reserve, despite holdings that these excessive funds nevertheless belong to investors, ${ }^{138}$ it would appear that consumers were here repaying the investment in advance, and foregoing the use of their money for a longer period of time than necessary. Then it would seem equitable to apply the portion of the reserve representing the accumulated excessive depreciation as an alternative fund available to offset requirements, or, alternatively, to offset against the working capital allowance a figure representing interest payments on the consumers' advance payments. Excessive depreciation charges seldom arise, however, since the commissions themselves regulate the rate of depreciation, with power of revision for mistaken estimates.

Computing the Amount of Sources:-Having computed the total dollar amounts of each of the alternative sources of funds, it is next necessary to determine the average period of time for which the company has the use of these funds. This will be done by studying the lag in time between the receipt of each alternative source of funds and the ultimate application of those funds to payment for the goods or services for which they are intended. ${ }^{139}$ The figure thus obtained will be used to offset against the comparable working capital requirement figure obtained above. ${ }^{140}$ The final step in the process is to determine which of these two figures is larger, the requirements or the alternative sources. If the alternative sources prove greater than the requirements, no allowance should be made in the rate base for working capital (including materials and supplies), since the excess proves that the company need not employ investors' funds for this purpose, but has available for use cash obtained from customers, creditors, banks, parent companies, and reserves; it does not matter whether the company actually uses these alternative funds, since they are available for use and since the rate base is intended to permit the company's owners to earn a return only on the amount they have properly invested in used and

138. E.g., Peoples Natural Gas Co. v. Pennsylvania PUC, $153 \mathrm{~Pa}$. Super. 475, 34 A.2d 375 (1943) (particularly at 516-20, 34 A.2d 375, 389-91 of concurring opinion).

139. For example, a consumer paying his January telephone bill includes payment for federal taxes which the company will have to pay to the government in installments in March, June, September and December of the following year. A study of these customer tax payments might reveal that at all times the company can expect to have available accumulations of taxes (amounting, let us say, to $\$ 400$ a day) which are paid to the government an average of 250 days later, thus giving a lag of 100,000 dollar-days. Also, a supplier may give to the utility 30 days' credit for his $\$ 100$ invoice, which means that the utility has a source of credit worth 3,000 dollar-days. The utility may pay a second $\$ 100$ invoice to a supplier within 10 days, taking a $2 \%$ discount. This means not only that in computing requirements only $\$ 98$ will be considered, but also that the utility has available a 10 day credit of the $\$ 98$ to offset against its accumulated requirements, to the extent of 980 dollar-days. Adding these three sources together, the company each day has an average of $\$ 103,980$ available to offset against its average working capital requirements for that day. Dividing this by the total amount of the three bills (\$598) gives a weighted average lag of 173.9 days.

140. See text following note 101 supra. 
useful property, including working capital. Such a result would follow regardless of the theory used for valuation of tangible assets for rate base purposes.

\section{Suggested New Approach}

A method such as that followed by most commissions today, even though made internally consistent and adopting more careful scrutiny of all of the items constituting the requirements and sources, is based on average lags in payments by the customer and by the company, and average availability of alternative sources. It is predicated on the theory that the demand for services from the utility is fairly constant during the year, even if the bills which the company pays and the revenues it receives are not. Extraordinary peaks in demand resulting in an uneven allocation of cost over the year are not necessarily reflected in a corresponding peak in availability of sources; in fact, they are only partially disclosed and considered by a study of lags and a matching of revenue against cost of particular services. The above method may also prove complicated and lengthy, as is apparent from the computation described. Another approach is available, characterized by relative simplicity and utilizing language easily understood and commonly used by managers of utilities. This method involves a redefinition of terms and a reorientation toward the problem, taking into consideration peak needs of the utility, rather than average figures.

Any cash outlay whatsoever, provided it constitutes a legal use of utility funds, and provided also that such an outlay is not includable elsewhere in the rate base (as is, for example, payment for plant acquisition), ${ }^{141}$ gives rise to a working capital requirement. It includes cash payments for retirement of bonds, interest charges, payrolls, materials and supplies, various other expenses including taxes, bills from suppliers, and dividends for investors. It also includes cash outlays for maintaining minimum bank balances and petty cash funds. Certain non-cash outlays also represent working capital requirements; these include any lawfully incurred bills for any item which, if paid in cash, would represent a cash requirement. (But if payment of these liabilities in the latter category can be postponed, the credit will offset the corresponding amount of requirements, as discussed below.) A study of these estimated future requirements will be made as of various times during the year, most likely at billing dates. This will give a picture (really a series of pictures) of the components of the company's financial position, showing how much the company will actually need at various times during the year to keep it operating.

141. This is where the estimate differs from a managerial study. At the beginning of each fiscal period management makes a study of all of its cash needs including that needed for plant extension, additions and betterments, and retirement of plant. It does not limit its study to working cash requirements. It also determines the amount of funds and other sources, which it will have available for all purposes, including the reserve for depreciation, which is available for replacement of assets written off against that reserve. See text following note 26 supra. 
All accumulated funds, whether from customers' payments for services, other income items, borrowings from banks or parent companies, sales of stock, or available cash funds being accumulated by the company for any purpose at all, represent sources which can be used to meet the requirements. Non-cash items such as credit extended by suppliers or loans from banks are also considered sources, since they postpone the need for meeting the working capital requirements, although they themselves represent requirements on the dates when they have to be repaid to the suppliers or banks. The commission will have to study the amount and sources of all of these accumulated funds used to meet the requirements at the estimated dates required. The working capital allowance properly to be granted by the commission will be the amount of those funds necessarily supplied by the investors to meet the legitimate peak requirements; no allowance will be granted if other sources are available which would cost the customer less than the fair return they will have to pay on the investors' money.

An example will clarify this explanation. Assume that a utility has to pay salaries amounting to $\$ 10,000$ twice a month; it may be billed by suppliers at the end of each month to the extent of $\$ 30,000$; on June 30 it expects to pay annual dividends to investors amounting to $\$ 50,000$, and $\$ 35,000$ on December 30. In November it will have to pay an annual bonus of $\$ 10,000$ to employees. Each of these expenditures represents a legitimate working cash requirement; money or credit will have to be available to the company at these times to meet its obligations. Suppose that the company bills its customers monthly and they pay promptly at the beginning of each month; it expects to obtain revenues from consumers of $\$ 55,000$ each month during the year, but $\$ 80,000$ in December, its peak period. Thus the company expects to obtain $\$ 55,000$ early in January; it will have on hand sufficient funds to pay the two $\$ 10,000$ payrolls during January and to meet the suppliers' bills of $\$ 30,000$ at the end of the month, and will be able to put aside $\$ 5,000$. The same will be true each succeeding month until and including the month of May. By the end of May the company will have set aside $\$ 25,000$. During June it will collect $\$ 55,000$ more from customers, giving it a total supply of cash of $\$ 80,000$. It will meet its first payroll of $\$ 10,000$; then at the end of the month it will be faced with obligations of $\$ 10,000$ for payroll, $\$ 30,000$ for suppliers, and $\$ 50,000$ for dividends (which we will assume is a legal declaration of dividends representing profits) ; it will have available only $\$ 70,000$ cash to meet these total obligations of $\$ 90,000$. If the company can obtain credit from its suppliers enabling it to postpone for 30 days the payment of the $\$ 30,000$ bills, it will be able to meet the remaining $\$ 60,000$ obligations from its available cash funds, leaving a balance of $\$ 10,000$ in cash. During July the company will obtain $\$ 55,000$ more revenue, but will be faced with $\$ 20,000$ payroll, $\$ 30,000$ bills from suppliers for the month, $\$ 30,000$ representing the bills of the previous month. Assuming that no further credit is available from suppliers, the company will have to obtain $\$ 15,000$. elsewhere. Assume 
that it can make a 90 day loan from a bank at $4 \%$ interest a year (or $1 \%$ for the 90 days); no money need yet be borrowed from investors. During August and September the company will be able to meet its $\$ 50,000$ obligations from the $\$ 55,000$ revenue, so that in October it has available $\$ 10,000$ besides the $\$ 55,000$ revenues. But in October not only will it have the ordinary obligations of $\$ 50,000$, but it will have to repay the loan made in July, plus $1 \%$ interest, totalling $\$ 15,150$. This will leave the company $\$ 150$ short. Assuming that the company is unable to obtain either credit or further bank loans, this $\$ 150$ will have to be supplied by investors. In November the company will obtain $\$ 55,000$ revenue, will sustain $\$ 50,000$ bills, plus the $\$ 10,000$ bonus. Again assume that no credit or loans are available, the extra $\$ 5,000$ will have to be obtained from investors. In December the company will receive $\$ 80,000$ revenues, leaving it $\$ 5,000$ short after the $\$ 50,000$ bills and $\$ 35,000$ dividends are paid; again this will have to be met by investors. Thus the investor is entitled to a fair return on the amount he has invested in the company to meet its peak requirement which amounts to $\$ 10,150$ here. Assuming the fair rate applied to the rest of the rate base to be $6 \%$, the investor is entitled to $6 \%$ of the $\$ 10,150$ invested and retained by the company for the entire year, or $\$ 609$, in addition to the return on the tangible assets in the rate base. Of course the $\$ 10,150$ will not be used for working capital purposes during the entire year. When it is not being so used, it will be (or should be) invested in other safe but productive investments, such as government bonds; the income thus obtained will appear in the company's accumulated funds available to offset some working capital requirements until the bonds have to be sold to supply the needed fund for the peak needs. (If the company does not actually invest it, but merely keeps it in an unproductive use, the commission ought to deduct an amount equivalent to the income that would have been earned had it been invested by efficient management.)

One of the advantages of this method is the fact that the commission makes a determination of the feasibility and advisability of seeking any loans, credit, or even a change in billing practices to provide greater accumulations of cash to meet the various peak requirements of working capital. If the commission concludes that such alternative sources are available to the company without impairing its financial or fiscal standing, it will make no allowance in the rate base for such funds. While it is recognized that the utility management has the right to make fiscal and other managerial decisions without interference by the commission or courts, ${ }^{142}$ it is a commission function to protect the consumer from paying excessive rates on management practices which are unwise but which do not amount to an abuse of discretion. This scrutiny will encourage the company to seek its required cash elsewhere, rather than using investors' money, since the company must continue to provide a fair return on the money supplied by investors if it wishes to attract new capital and retain 
it. The commission will therefore have some long-run supervision over the fiscal policies of the utility, and will be able to protect the consumer from excessive charges in the rate base.

\section{Summation}

The problem of the working capital allowance arises from the fact that at various times during the year a utility may have to make cash disbursements in excess of funds accumulated from all sources other than invested cash. If this excess must be met by using investors' money, this money should earn a fair return in order to encourage its continued investment in the utility, just as a fair return is paid on money invested in fixed plant. If, however, it can be met from other sources, such as customers' advances for taxes or other prepaid expenses, bank loans, loans from parent companies, or suppliers' credit, utilization of these alternative sources would prove cheaper to the consumer than payment of a fair return on the same amount of investors' capital, even if the customers paid for the cost of these alternative sources, such as loans. Refusal to allow any figure for working capital does not mean that the company is likely to find itself unable to meet its debts; maintaining a supply of funds necessary to meet these expenses is a managerial function which is not being tusurped by the regulating commission. But an accurate estimate of the amount and sources of the funds needed to meet legitimate outlays and to maintain a sound financial position will enable the commission to require the consumer to pay a fair return on only that amount of funds necessarily supplied by investors. How to make such an accurate estimate is the major problem. As to most fiscal and managerial decisions, the company's determination should not be disturbed unless it constitutes an unreasonable exercise of discretion inconsistent with public welfare; the regulatory commission, which is not directly responsible or accountable for failure of the business, should minimize its interference. But the management's decision as to matters affecting rates charged to consumers should not be considered binding. The public cannot rely on ordinary competitive conditions to protect its interest. Public utilities occupy a unique position in our economy; they enjoy a virtual monopoly of supply, largely untrammelled even by availability of substitutes, and a comparative inelasticity of demand. This means that rates set by commissions must be pegged largely to cost or value of service in order to encourage capital investment in such utilities, since ordinary competitive guides are absent. Thus a determination of the working capital practices of utilities should not be binding in setting rates, nor would a comparison of utility needs with those of other companies of comparative size and. stability be appropriate. A method of balance sheet analysis or study of the amounts actually kept by the company may reward inefficient utilization of sources, since such conditions may be largely of the company's own making and may be entirely unrealistic pictures of the company's actual legitimate needs. A careful 
study of both requirements and sources, based on average percentages of lags in payment of the utility's expenses and in receipts from customers, is consistent with the purpose of the allowance and tends to protect customers from inefficient use of cash funds. But this method is subject to the criticism that it is unrealistic in that it is based on averages, and may also be complicated. A study of the actual requirements at peak periods during the years and of the sources and amounts of accumulated funds used at those times to meet those requirements is simpler and more in line with the actual study made by management and commissions each year. At best any estimate is merely a considered guess; but the commission should use that guess to protect consumers and discourage inefficient fiscal policies. Even without an allowance the utility managers might use investors' funds for working capital purposes; but if the utility found itself unable to pay a fair return on such funds, it would not be long before investors would either require a change in managerial policy or withdraw their investment. Thus, the commission would be able to maintain a suasive power over the fiscal policies of the company, including its practices in relation to borrowing from banks or parent companies, using accumulated reserves, and even in billing of customers.

The recent curbs on the working capital allowance are justifiably considered by utility operators to represent a threat ${ }^{143}$ to the return they seek for their investors. The operators also fear that the alternative funds approach may be extended to require offsetting of such funds against the entire rate base, not just working capital. Such an extension would be too severe, since these funds can seldom be used for the purpose of fixed plant. However, it would be logically consistent with the alternative funds approach to require offsetting against the rate base at least those reserves set up by charges to operating expenses (such as reserves for injuries, insurance, or contingencies), since they represent funds supplied by customers which are available for purchase of plant. ${ }^{144}$ Consumers stand to benefit by the current trend, both because of the elimination of excessive charges and because rising prices, reflected in a consequently larger supply of alternative funds such as income tax accruals, can be used to offset the need for higher rates. Balancing the divergent interests of the utility investor and the unorganized consumer requires commissions of high caliber aided by appropriate investigatory tools. Present valuation procedures are ill-adapted to attaining the goals of regulation; more searching inquiries into both the purposes and means of regulation, such as suggested by the recent trends in the working capital computation, will help achieve those goals.

\section{See 48 P.U. ForT. 744 (1951).}

144. This has been suggested by an attorney who represents consumer interests in many rate cases; while it has not yet been accepted by the courts, it appears logically consistent with the approach suggested here and largely accepted by courts today. 